\title{
Should We Keep Walking along the Trail for Pancreatic Cancer Treatment? Revisiting TNF-Related Apoptosis-Inducing Ligand for Anticancer Therapy
}

\author{
Anna-Laura Kretz ${ }^{1}$, Silvia von Karstedt ${ }^{2,3}$, Andreas Hillenbrand ${ }^{1}{ }^{(\mathbb{D}}$, Doris Henne-Bruns ${ }^{1}$, \\ Uwe Knippschild $^{1}$, Anna Trauzold ${ }^{4,5}$ and Johannes Lemke ${ }^{1, * \text { (D) }}$ \\ 1 Department of General and Visceral Surgery, Ulm University Hospital, Albert-Einstein-Allee 23, 89081 Ulm, \\ Germany; anna-laura.kretz@uni-ulm.de (A.-L.K.); andreas.hillenbrand@uniklinik-ulm.de (A.H.); \\ doris.henne-bruns@uniklinik-ulm.de (D.H.-B.); uwe.knippschild@uniklinik-ulm.de (U.K.) \\ 2 Department of Translational Genomics, University Hospital Cologne, Weyertal 115b, 50931 Cologne, \\ Germany; s.vonkarstedt@uni-koeln.de \\ 3 Cologne Excellence Cluster on Cellular Stress Response in Aging-Associated Diseases (CECAD), \\ University of Cologne, Joseph-Stelzmann Straße 26, 50931 Cologne, Germany \\ 4 Institute for Experimental Cancer Research, University of Kiel, 24105 Kiel, Germany; \\ atrauzold@email.uni-kiel.de \\ 5 Clinic for General Surgery, Visceral, Thoracic, Transplantation and Pediatric Surgery, \\ University Hospital Schleswig-Holstein, 24105 Kiel, Germany \\ * Correspondence: johannes.lemke@uniklinik-ulm.de
}

Received: 28 February 2018; Accepted: 14 March 2018; Published: 18 March 2018

\begin{abstract}
Despite recent advances in oncology, diagnosis, and therapy, treatment of pancreatic ductal adenocarcinoma (PDAC) is still exceedingly challenging. PDAC remains the fourth leading cause of cancer-related deaths worldwide. Poor prognosis is due to the aggressive growth behavior with early invasion and distant metastasis, chemoresistance, and a current lack of adequate screening methods for early detection. Consequently, novel therapeutic approaches are urgently needed. Many hopes for cancer treatment have been placed in the death ligand tumor necrosis factor (TNF)-related apoptosis-inducing ligand (TRAIL) since it was reported to induce apoptosis selectively in tumor cells in vitro and in vivo. TRAIL triggers apoptosis through binding of the trans-membrane death receptors TRAIL receptor 1 (TRAIL-R1) also death receptor 4 (DR4) and TRAIL receptor 2 (TRAIL-R2) also death receptor 5 (DR5) thereby inducing the formation of the death-inducing signaling complex (DISC) and activation of the apoptotic cascade. Unlike chemotherapeutics, TRAIL was shown to be able to induce apoptosis in a p53-independent manner, making TRAIL a promising anticancer approach for p53-mutated tumors. These cancer-selective traits of TRAIL led to the development of TRAIL-R agonists, categorized into either recombinant variants of TRAIL or agonistic antibodies against TRAIL-R1 or TRAIL-R2. However, clinical trials making use of these agonists in various tumor entities including pancreatic cancer were disappointing so far. This is thought to be caused by TRAIL resistance of numerous primary tumor cells, an insufficient agonistic activity of the drug candidates tested, and a lack of suitable biomarkers for patient stratification. Nevertheless, recently gained knowledge on the biology of the TRAIL-TRAIL-R system might now provide the chance to overcome intrinsic or acquired resistance against TRAIL and TRAIL-R agonists. In this review, we summarize the status quo of clinical studies involving TRAIL-R agonists for the treatment of pancreatic cancer and critically discuss the suitability of utilizing the TRAIL-TRAIL-R system for successful treatment.
\end{abstract}

Keywords: TRAIL; pancreatic adenocarcinoma; TRAIL-R agonists 


\section{Introduction}

Typical characteristics of cancers are self-sufficiency in growth signals, enhanced proliferative signaling, invasion, metastasis, angiogenesis, replicative immortality, and resistance to cell death $[1,2]$. Pancreatic ductal adenocarcinoma (PDAC) harbors all of these classical hallmarks. Reduced response to conventional cytotoxic therapies is the culprit responsible for tumor development and progression despite therapy [3,4]. A less conventional therapeutic approach for PDAC arises from the stimulation of extrinsic apoptosis by death ligands. Accordingly, appropriate expression of respective death receptors (DR) on the plasma membrane and a functional downstream signaling apparatus is required to successfully stimulate the extrinsic apoptosis cascade reviewed in [4-6]. tumor necrosis factor (TNF)-related apoptosis-inducing ligand (TRAIL/Apo2L) and its pro-apoptotic receptors TRAIL receptor 1 (TRAIL-R1) and 2 (TRAIL-R2) represent such a death ligand/receptor system. On the one hand, the TRAIL-TRAIL-R system is expressed by PDAC cells and, on the other hand, capable of activating apoptosis selectively in tumor cells by binding to its death receptors reviewed in [7].

\subsection{Pancreatic Cancer}

Adenocarcinomas of the pancreas are nowadays still a significant health problem accounting for some 367,000 newly diagnosed patients in 2015 a number that keeps rising [8,9]. Compared to other solid tumor entities, pancreatic cancer has the highest mortality rate and is the fourth leading cause of cancer-related deaths worldwide $[9,10]$. Despite recent advances in diagnosis and treatment of PDAC, prognosis remains very poor, with a 5-year overall survival below $7 \%$ and a median survival upon diagnosis of 6 months $[10,11]$. This is mainly due to the aggressive phenotype of pancreatic cancer cells with highly invasive and metastatic potential. The only chance for cure is surgical resection $[12,13]$. However, due to vague and unspecific symptoms and lack of biomarkers, in most cases $(80 \%)$ diagnosis only occurs at a locally advanced/metastatic and accordingly incurable stage. For these patients, treatment remains palliative to potentially alleviate symptoms and limit tumor growth [11,14]. Of note, tumor resected patients with curative interventions also frequently develop local tumor recurrence and/or metachronous metastases reducing long-term survival and potential cure [15].

Since 1997, monotherapy with gemcitabine (Gemzar), a synthetic pyrimidine nucleoside prodrug, was considered as the gold standard of care for PDAC. The nucleoside is an analog of deoxycytidine and is transferred to its active form by phosphorylation within the cell, eventually preventing DNA synthesis by incorporation into DNA. The efficacy of the substance is marginal as median survival is only prolonged by weeks to months. [16,17]. Consequently, combinatorial treatment strategies with gemcitabine were investigated the following two decades, again with unsatisfactory outcomes. However, improved response to therapy could be eventually achieved applying either the FOLFIRINOX (FOL-folinic acid-leucovorin, F-5-fluorouracil (5-FU), IRIN-irinotecan, OX-oxaliplatin) regimen [18] or the gemcitabine-nab (nanoparticle albumin-bound)-paclitaxel approach [17,19-21]. The folinic acid leucovorin is a vitamin B derivative to reduce side effects of 5-FU, a pyrimidine analog which incorporates into the DNA molecule and avoids DNA synthesis [22,23]. Irinotecan acts as DNA topoisomerase I inhibitor, which stops uncoiling and duplication of DNA [24]. Oxaliplatin, a diaminocyclohexane platinum compound, forms platinum-DNA adducts which block DNA replication [25]. Nab-paclitaxel is an example of nanotechnological cancer therapy. In this formulation, paclitaxel, first isolated in 1971 from the Pacific yew and described as an antitumor drug [26] is linked to albumin nanoparticles thereby increasing the agent's solubility. The microtubule-stabilizing activity of paclitaxel enhances microtubule polymerization and $\mathrm{G}_{2} / \mathrm{M}$ phase arrest of the cells $[27,28]$. The FOLFIRINOX regimen and gemcitabine-nab-paclitaxel approach are the two combinatorial regimens which are the present standard treatments for advanced PDAC patients with good performance statuses. However substantial and severe toxic effects are reported when applying these regimes $[21,29,30]$. Meanwhile, therapy benefit for patients is still unsatisfactory. Notably, owed to the intrinsic or acquired resistance to apoptosis, pancreatic tumor cells are widely insensitive 
to conventional radio- and chemotherapy, mainly narrowing their efficiency [4,15]. Since apoptosis resistance to cell death is a hallmark of PDAC, only research into responsible molecular mechanisms will provide new treatment avenues towards targeted therapy $[1,4,31]$.

\subsection{TRAIL and TRAIL Receptors}

A more in-depth understanding of tumor biology and the interplay between tumor and immune system promotes research into 'targeted' cancer therapy. One step in this direction was the identification of TRAIL, also referred to as Apo-2 ligand (Apo2L) in the mid-1990s [32,33] and its ability to induce apoptosis selectively in cancer cells while sparing healthy cells [34,35].

TRAIL is a member of the TNF-superfamily (TNF-SF) with the ability to induce apoptosis in cells by engagement of the DRs TRAIL-R1/DR4 (also called APO-2 or TNFRSF10A) [36] and TRAIL-R2/DR5 (TNFRSF10B, TRICK2, KILLER) [37] at the plasma membrane. Physiological full-length TRAIL is a type II transmembrane protein, constitutively expressed in a variety of tissues $[32,33]$. For many years, only limited data existed about the responsible proteolytic enzyme(s) involved in TRAIL cleavage aiding the release of its soluble form. Then, the protease cathepsin E was identified to release the 24 $\mathrm{kDa}$ extracellular portion of the ligand from the cell surface [38]. Similar to most TNF family members, the ligand forms homotrimers engaging three receptors [39,40]. In 1999, the crystal structure of the extracellular domain of human TRAIL was described, revealing that TRAIL monomers are composed of two antiparallel $\beta$-sheets which form a $\beta$ sandwich as the core structure. The interplay of the TRAIL monomer with the adjacent subunits generates a bell-shaped homotrimer [41]. In order to stabilize and presumably mediate solubility and bioactivity of the ligand, an internal zinc atom interacts noncovalently with three cysteine residues, one supplied from each ligand monomer [42]. The crystal structure of TRAIL interacting with TRAIL-R2 revealed the trimerization of the TRAIL-R upon binding of the TRAIL trimer [39]. In healthy adults, the constitutive plasma concentration of soluble TRAIL is about $100 \mathrm{pg} \mathrm{mL}^{-1}$. Interestingly, at this concentration TRAIL exhibits no apoptosis-inducing activity in most cell lines and its function is therefore unknown $[43,44]$.

In addition to TRAIL-R1 and TRAIL-R2, TRAIL can bind the receptors TRAIL-R3 and TRAIL-R4 also referred to as decoy receptor 1 (DcR1) alternative TNFRSF10C, TRID, or LIT and decoy receptor 2 (DcR2) alternative TNFRSF10D, or TRUNDD, respectively, as well as to the soluble receptor osteoprotegerin (OPG, TNFRSF11B) [5,45-48]. TRAIL-R1 and TRAIL-R2 signal apoptosis via their conserved death domain (DD) motif $[37,47,49,50]$, whereas the DcRs have been shown to negatively regulate TRAIL-induced apoptosis [reviewed in 47]. TRAIL-R3 is attached to the plasma membrane via a glycophosphatidyl (GPI) anchor but lacks an intracellular domain, whilst TRAIL-R4 contains a truncated intracellular DD $[5,36,47,49,50]$. Overexpression experiments displayed the inhibitory potential of TRAIL-R3 and TRAIL-R4 regarding apoptosis induction by ligand scavenging and/or interaction with the death receptors [51-53] and down-regulation of the decoy receptors sensitized to TRAIL-induced apoptosis [54,55]. OPG, a soluble receptor identified to bind TRAIL, was initially demonstrated to regulate osteoclastogenesis by interaction with the receptor activator of nuclear factor $\mathrm{kB}$ ligand (RANKL). Notably, under physiological conditions the affinity of TRAIL for OPG is significantly weaker compared to the other TRAIL receptors [56,57], suggesting that OPG might play a subordinate role in modulating TRAIL-signaling. This may hold true since TRAIL present at low concentrations rather favors high-affinity binding to TRAIL-R2. Overall, the death-inducing TRAIL-receptors show higher affinity for TRAIL than the decoy receptors [58]. Since TRAIL-R2 exhibits the highest affinity for TRAIL at $37^{\circ} \mathrm{C}$, TRAIL-R2 was initially expected to be the primary inducer of TRAIL-induced apoptosis. However, this principal concept of TRAIL-R2 is questionable since it was uncovered that TRAIL-R1 is the primary inducer of apoptosis in pancreatic cancer cells and chronic lymphocytic leukemia even though TRAIL-R2 is expressed [59-62]. Synthetic TRAIL-R2-specific TRAIL variants were more efficient than wild-type TRAIL in killing PDAC [63]. Moreover, other data suggest that in certain scenarios also TRAIL-R2 might be the preferred TRAIL-R, mediating apoptosis in PDAC [64]. TRAIL-R1 and TRAIL-R2 share high sequence homology to a high degree 
(58\% identical) $[36,65]$ and so far, it is still enigmatic why two death-inducing TRAIL-Rs are expressed in humans. Two splice variants of TRAIL-R2 have been identified (long and short form), which differ by 29 amino acids in the extracellular domain. Moreover, the predominant occurrence of the long isoform was reported, whereas the ratio of the two isoforms differs in a tissue-dependent manner [66].

In comparison to the human system, mice only express one receptor capable of inducing apoptosis termed mTRAIL-R (MK) with $43 \%$ and $49 \%$ sequence homology to human TRAIL-R1 and TRAIL-R2, respectively [67]. However, the decoy receptors mDcTRAIL-R1 (TNFRS23) and mDcTRAIL-R2 (TNFRS22) lack a DD and differ substantially in their amino acid sequence from their human counterparts. Furthermore, they are not able to induce apoptosis [68]. Noteworthy, affinity of human TRAIL to the murine receptors is weak. Conversely, murine TRAIL interacts strongly with the human receptors [69].

A graphical representation of TRAIL and its receptors in humans and mice is presented in Figure 1.

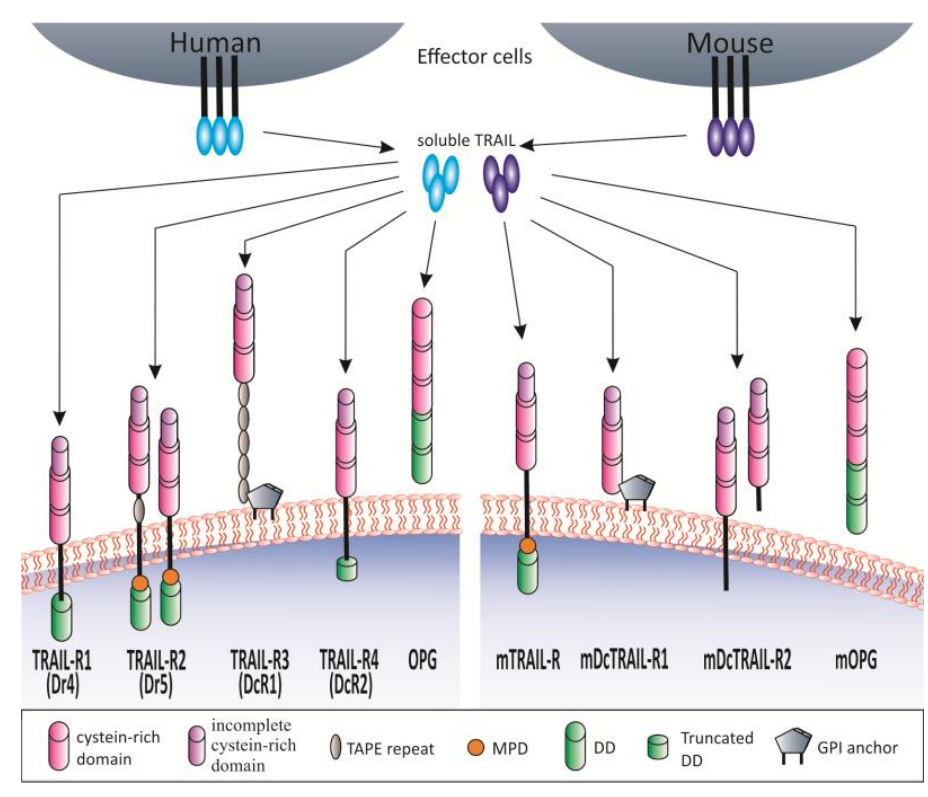

Figure 1. The human and murine tumor necrosis factor (TNF)-related apoptosis-inducing ligand (TRAIL)-TRAIL-receptor (TRAIL-R) system. TRAIL-TRAIL-R-system in humans. Human tumor-necrosis-factor-related apoptosis-inducing ligand (TRAIL) can engage four membrane-bound TRAIL-Rs and one soluble receptor, while two of these receptors can promote apoptosis (TRAIL-R1 and TRAIL-R2) and three might serve as decoys. TRAIL-R1 and TRAIL-2 express an intracellular domain comprising a death domain (DD), required for apoptosis induction. TRAIL-R2 occurs as short or long isoform, distinguishable by the absence or presence of a single TAPE (threonine/alanine/proline/glutamine) domain. TRAIL-R3 is attached to the membrane via a glycosylphosphatidylinositol (GPI) anchor and expresses five TAPE domains, but no intracellular domain. TRAIL-R4 merely expresses a truncated DD incapable of transmitting an apoptotic signal. Osteoprotegerin (OPG) represents the soluble receptor with low affinity for TRAIL. Cysteine-rich domains of the receptors are crucial for ligand binding. TRAIL-TRAIL-R-system in mice. Mice express four receptors for TRAIL, while mTRAIL-R is homologous to human TRAIL-R1 and TRAIL-R2. mDcTRAIL-R1 and mDc-TRAIL-R2 differ from the human forms. mOPG is the soluble receptor for TRAIL in the murine system. MPD, membrane-proximal domain.

\subsection{Apoptotic Signaling}

Apoptosis is a form of programmed cell death (PCD) and the central player in tissue homeostasis and embryogenesis first described in 1972 [70,71]. This cellular suicide mechanism designates the elimination of redundant, damaged, or infected cells by phagocytosis. It can be initiated either intrinsically via DNA damage, growth factor deprivation and cytotoxic stress and is in such cases 
termed intrinsic apoptosis or via extracellular death ligand binding to a death receptor (extrinsic apoptosis pathway). In all cases, apoptosis results in cell shrinkage, nuclear condensation, DNA fragmentation, and formation of apoptotic bodies. Caspases orchestrate these phenotypic hallmarks via cleavage of various target proteins [71-73].

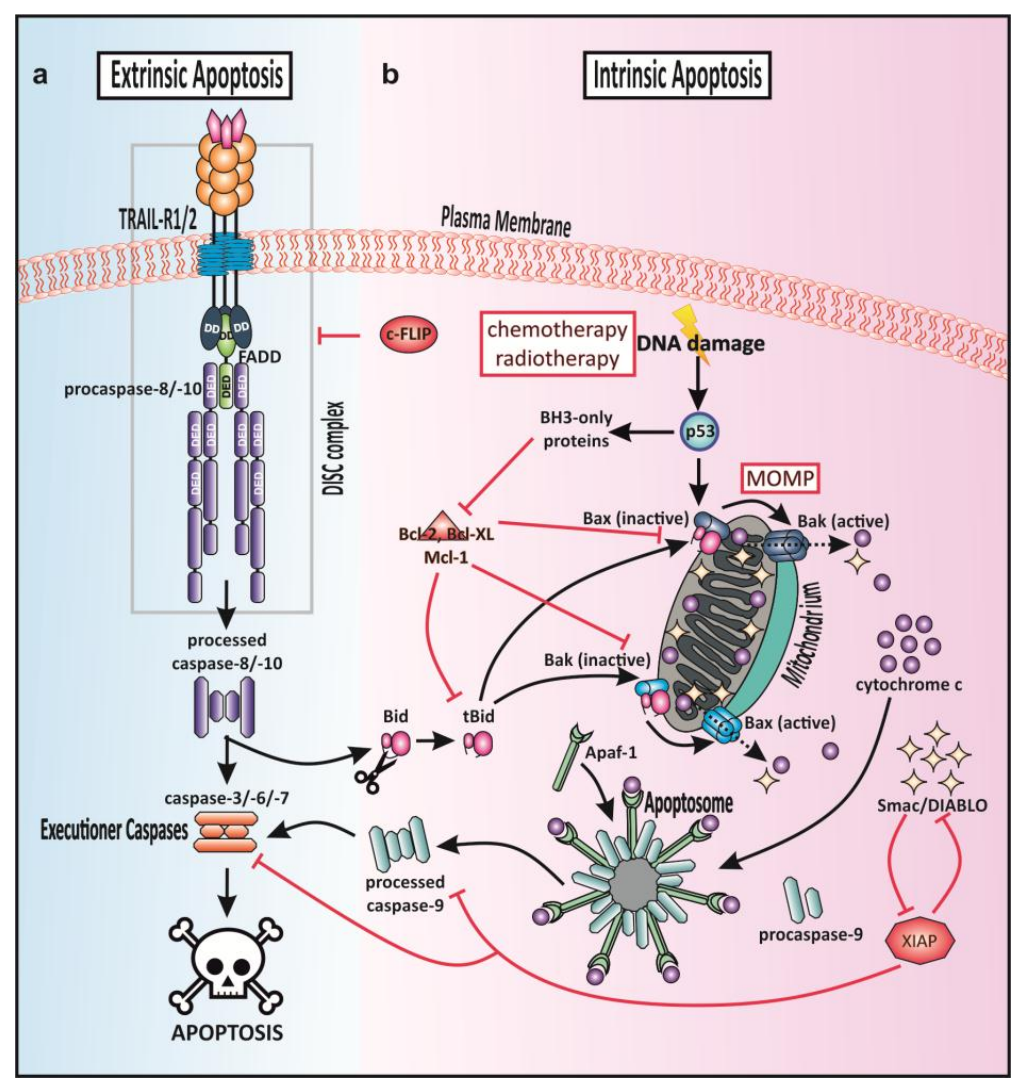

Figure 2. Apoptotic signaling. (a) Tumor necrosis factor-related apoptosis inducing ligand (TRAIL)-induced extrinsic apoptosis. Upon TRAIL binding to TRAIL receptor 1 (TRAIL-R1) and/or TRAIL receptor 2 (TRAIL-R2) the death-inducing signaling complex (DISC) is formed. In type I cells, the signal of DISC-activated caspase- 8 is sufficient to activate downstream effector caspase- 3 and therefore apoptosis, whereas the DISC signal needs amplification by mitochondrial apoptosis via caspase-8-dependent cleavage of the B cell lymphoma 2 (Bcl-2) homology domain 3 (BH3) interacting domain death agonist (Bid) in type II cells. Truncated Bid (tBid) translocates to the mitochondria and triggers the $\mathrm{Bcl}-2$-family members $\mathrm{Bcl}$-2-associated $\mathrm{X}$ protein (Bax) and $\mathrm{Bcl}-2$ homologous antagonist killer (Bak) in the mitochondrial outer membrane (MOM), resulting in its permeabilization (MOMP) and eventually cytochrome $\mathrm{c}$ and second mitochondrial activator of caspases/direct inhibitor of apoptosis-binding protein with low $\mathrm{pI}$ (Smac/DIABLO) release. Apoptotic protease activating factor-1 (Apaf-1) complexes with cytochrome $\mathrm{c}$ and caspase-9 to build the apoptosome promoting effector caspases-3, -6 and -7. (b) Intrinsic death signaling. In response to stress signals, p53 becomes activated thereby triggering BH3-only proteins resulting in MOMP. In type I cells, DISC formation is sufficient to activate caspase- 8 for activation of the executioner caspase- 3 . In type II cells, DISC formation is enhanced by MOMP to neutralize the caspase-inhibitory protein X-linked inhibitor of apoptosis protein (XIAP). XIAP binds to and potently inhibits caspase-3, -7 and -9. Several apoptosis regulation mechanisms are known: Fas-associated death domain (FADD)-like IL-1 $\beta$-converting enzyme (FLICE)-inhibitory protein (c-FLIP) and caspase- 8 compete for binding to FADD. Thus caspase-8 activation is repressed. In type II cells, binding of Bcl-2, B-cell lymphoma-extra-large (Bcl-XL) or induced myeloid leukemia cell differentiation protein (Mcl-1) to Bax and Bak, converts them into their inactive forms. Smac/DIABLO binds to and antagonizes XIAP and thereby ensures potent activation of caspases-3, -7 and -9 . 
Chemotherapy usually results in the induction of intrinsic apoptosis via p53 in response to DNA damage. The functionality of the tumor suppressor p53 is, therefore, a requirement for apoptosis induction. However, p53 is inactivated in around $70 \%$ of pancreatic tumors. Nevertheless, signaling through death receptors to induce apoptosis is still possible in many cases despite p53 inactivation $[6,10,14,74-77]$. In Figure 2, extrinsic and intrinsic apoptosis pathway are summarized.

\subsection{TRAIL-Mediated Cell Death Signaling-Extrinsic Apoptosis}

The anti-tumor activity of TNF was first identified unknowingly when William B. Coley used dead bacteria (Coley's toxins) to treat cancer at the end of the 19th century [78]. 100 years later, Old et al. demonstrated that this activity was attributable to a polypeptide, produced after bacterial infection. The hemorrhagic necrosis of treated tumors led to the polypeptide's naming tumor necrosis factor in the 1970s [79]. TNF was enthusiastically debated as a novel potential anticancer substance for several years. However, it was revealed that canonical TNF-induced signaling triggers pro-inflammatory signaling pathways rather than apoptosis in most scenarios. Consequently, systemic application of TNF resulted in severe systemic inflammatory response syndrome reviewed in [80]. Novel hope was then placed in the discovery of the death receptor (DR) TNF superfamily receptor 6 (Fas)/apoptosis antigen 1 (APO-1) also called CD95 and the development of respective agonistic antibodies, reported to induce apoptosis in a variety of cancer cells [81-84]. Again, initial optimism was destroyed when fulminant and lethal hepatotoxicity was noted after systemic treatment with anti-Fas [85]. Subsequently, the sequence homology to TNF and Fas led to the identification and cloning of TRAIL [32,33]. Most striking this time, was the capability of TRAIL to selectively kill cancer cells in vivo without causing toxicity $[34,35]$.

In response to TRAIL engaged with TRAIL-R1 and/or TRAIL-R2, extrinsic apoptosis is induced by the assembly of a signaling platform named the death-inducing signaling complex (DISC). In addition to TRAIL-Rs, this complex comprises the adaptor molecule Fas-associated death domain (FADD) and the initiator caspase-8/10 [86]. The exact stoichiometry of the TRAIL-DISC was uncovered in 2012 through quantitative mass spectrometry, revealing that three TRAIL-R1/R2 receptors recruit one FADD molecule which in turn recruits several procaspase-8 molecules [86]. The homotypic interaction of the death domain (DD) of FADD with the receptors respective DDs represents the bottleneck for activation of the TRAIL-mediated apoptosis pathway. FADD, in turn, enables the recruitment of procaspase- 8 and -10 via homotypic interactions of their death-effector domains (DED) with the corresponding DED of FADD $[3,45,86,87]$. Since procaspase- 8 contains two DEDs, a model proposed recently suggests that the first procaspase- 8 molecule binds FADD directly, but all further procaspase- 8 molecules bind to the free DEDs of the first procaspase- 8 molecule in a growing chain [88]. DISC formation enables procaspase- $8 /-10$ dimerization and proximity-induced activation required for initiation of the caspase cascade $[3,45,86-89]$.

The caspase-8 homolog cellular FADD-like IL-1 $\beta$-converting enzyme (FLICE)-inhibitory protein (c-FLIP) holds a crucial function in regulating caspase-8 activity within the DISC [90-92]. While this mechanism of regulation was initially understood to lie in a mere competition of c-FLIP and caspase-8 for binding to FADD, recent results support the idea that high levels of c-FLIP do not prevent direct caspase-8-FADD binding. The regulation rather occurs by suppressing elongation of caspase- 8 chains and thereby their activation [93]. Due to alternative splicing, several c-FLIP variants exist, of which the most predominantly expressed ones are c-FLIP long (c-FLIP $)$ and c-FLIP short (c-FLIPS) $[94,95]$. c-FLIP $\mathrm{L}_{\mathrm{L}}$ and full-length procaspase-8 are strictly homologous. However, a catalytic cysteine present in the active site of caspase- 8 and required for its proteolytic activity is absent in c-FLIP ${ }_{\mathrm{L}}$. c-FLIP $\mathrm{L}_{\mathrm{L}}$ has been associated with both death-promoting as well as survival-promoting functions, depending on expression levels and strength of receptor stimulation $[88,93,96]$. c-FLIPS comprises only DEDs $[95,97]$ and was shown to act in an anti-apoptotic manner.

In so-called type I cells, DISC formation is stable enough to sufficiently activate caspase- 8 for efficient activation of the executioner caspase- 3 resulting in apoptosis. In contrary, in type II cells, DISC-mediated initiation of the caspase cascade requires enhancement by mitochondrial outer 
membrane permeabilization (MOMP) to neutralize the caspase-inhibitory protein X-linked inhibitor of apoptosis protein (XIAP), a member of the inhibitor of apoptosis protein (IAP) family. XIAP binds to and potently inhibits caspase-3, -7 and -9 [98-102].

Pancreatic cancer cells have been classified as type II cells [103,104]. Consistently, members of the B cell lymphoma 2 (Bcl-2) family have been shown to crucially control extrinsic apoptosis in PDAC, as reviewed in [105]. The Bcl-2 family member Bcl-2 homology domain 3 (BH3) interacting domain death agonist (Bid) plays a major role in cross-signaling to mitochondria in response to DR activation. Upon DISC formation, active caspase-8 cleaves Bid generating truncated Bid (tBid), which translocates to mitochondria and eventually activates the mitochondrial cascade by triggering the oligomerization of the Bcl-2-family members Bcl-2-associated X protein (Bax) and Bcl-2 homologous antagonist killer (Bak), resulting in MOMP $[45,106]$. Following the pore formation in the mitochondrial membrane by Bak and Bax, the release of cytochrome $\mathrm{c}$ from the mitochondrial intermembrane space (IMS) to the cytosol is stimulated [107]. Once cytochrome $\mathrm{c}$ is present in the cytosol, apoptotic protease activating factor-1 (Apaf-1) triggers the assembly of the apoptosome, a stimulation platform for procaspase-9. Procaspase-9 holds an initiating function after activation through the apoptosome, promoting activation of effector caspases-3, -6 and -7 which execute apoptosis reviewed in [108].

Several regulation mechanisms are known which counteract excessive apoptosis. On DISC-level, c-FLIP and caspase- 8 compete for binding to FADD. Thus caspase- 8 activation is repressed and, consequently, execution of apoptosis [97]. In type II cells, binding of Bcl-2, B-cell lymphoma-extra-large (Bcl-XL) or induced myeloid leukemia cell differentiation protein (Mcl-1) to Bax and Bak, converts them into their inactive forms, thereby preventing MOMP $[109,110]$. Upon MOMP, in addition to cytochrome c, the second mitochondrial activator of caspases/direct inhibitor of apoptosis-binding protein with low $\mathrm{pI}$ (Smac/DIABLO) is released. Smac/DIABLO binds to and antagonizes XIAP and thereby ensures potent activation of caspases 3, 7, and 9 and execution of apoptosis [111,112].

\subsection{TRAIL-R Agonists in Clinical Trials}

In 1999, in vivo studies in mice, performed by two independent groups, revealed tumor regression after systemic treatment with recombinant variants of human TRAIL (rhTRAIL) [34,35]. This selective apoptosis-inducing effect of TRAIL on tumor cells while sparing healthy cells [34] provoked the clinical development of various TRAIL receptor-targeting agonists intended for cancer therapy. They can be subdivided into (i) recombinant human TRAIL variants and (ii) agonistic antibodies directed against TRAIL-R1 or TRAIL-R2 reviewed in [46]. Dulanermin (APO2L.0, AMG-951) is the only clinically available rhTRAIL ligand. The substance was not clinically evaluated for PDAC. Nevertheless, its suitability for this tumor entity will be revisited later with the aim to gain insights into the history of TRAIL-R agonist development. Only a few data are available on TRAIL-R-agonists in clinical trials for PDAC, these are the agonistic TRAIL-R2-specific antibodies conatumumab (AMG-655) and tigatuzumab (CS-1008). In the following section of this review article, these substances will be discussed in detail concerning their suitability for PDAC treatment.

\subsection{Recombinant TRAIL}

The challenge was to develop stable and active variants of recombinant TRAIL. Similar affinity for TRAIL-R1 and TRAIL-R2 might present a promising approach potentially enhancing death signals compared to stimulation of only one receptor. In this context, the death-inducing capacity might also be influenced by the different preference of TRAIL-R1 or TRAIL-R2 for apoptosis induction, varying tissue-dependently. Of note, in PDAC TRAIL-R1 is primarily used to trigger apoptotic cell death [59]. However, a potential problem regarding the therapeutic efficacy of recombinant TRAIL might arise from the fact that serum concentrations of active recombinant TRAIL available for TRAIL-R1 and -R2 binding might be downregulated by its binding to decoy receptors. In order to prolong half-life and stability of hrTRAIL, $N$-terminal tags such as poly-histidine tag [33], DYKDDDDK (FLAG) epitope [32] or leucine zipper (LZ) [34] motifs have been developed. Unfortunately, toxicology studies indicated 
that tagged recombinant TRAIL versions partially provoked hepatotoxicity, while this effect was absent with the use of non-tagged TRAIL [113].

To date, the only recombinant substance of human TRAIL approved for clinical use is dulanermin, an untagged variant based on amino acids 114-118 of the extracellular part of TRAIL [35]. Notably, dulanermin can bind both death-inducing receptors thereby providing a broader activity spectrum. However, the serum half-life of only 30-60 min actively restricts efficacy of the substance [114]. Dulanermin was clinically approved for non-small-cell lung cancer $[115,116]$, non-Hodgkin's lymphoma [117], metastatic colorectal cancer [118-120] and advanced cancer [114] in combination with chemotherapeutics. However, so far, in contrast to promising preclinical results [34,35], recombinant TRAIL failed as compared to standard therapy in clinical studies in the tumor entities mentioned. Although acceptable tolerability [114] was achieved in first in-human studies, significant antitumor effects were not observed as reviewed in $[7,121]$.

\subsection{TRAIL-R-Specific Agonistic Antibodies}

Compared to recombinant forms of TRAIL, agonistic TRAIL-R-specific antibodies exhibit higher stability and prolonged half-lives. Conatumumab (AMG-655), a fully human agonistic monoclonal antibody (IgG1) directed against TRAIL-R2, was shown to induce apoptosis in vitro and in pancreatic cancer xenograft models in vivo. Furthermore, AMG-655's activity cooperated with the antitumor potential of chemotherapeutics in PDAC in vivo models [122,123]. Following these encouraging preclinical results, phase I and II studies have been performed in patients with advanced PDAC [124-126]. AMG-655 was taken into a combination trial with gemcitabine in a phase $\mathrm{Ib}$ study in patients with metastatic pancreatic cancer to evaluate safety and efficacy. The study resulted in a disease control rate of $69 \%$ and a 6-month survival of $76.2 \%$ with acceptable tolerance in accordance with the first-in-human study [124,127]. Based on the results of the phase Ib study of AMG-655 combined with gemcitabine [124], a randomized placebo-controlled phase II study was performed in patients with metastatic pancreatic cancer comparing either ganitumab (AMG-479), a fully human anti-insulin-like growth factor receptor type I (IGF-1R) monoclonal antibody [128] or AMG-655 combined with gemcitabine. Trends were noted towards improved 6-month-survival. However, 12-month survival rate, overall survival, and patients' response were not superior in comparison to the gemcitabine monotherapy Trends were noted towards improved 6-month-survival. However, 12-month survival rate, overall survival, and patients' response were not superior in comparison to the gemcitabine monotherapy [126]. Tigatuzumab (CS-1008), the humanized form of the agonistic anti-TRAIL-R2 murine monoclonal antibody TRA-8, was made up of the complementarity-determining region of the murine $\mathrm{mAb}$ and the variable region framework and constant regions of human IgG-1 $\mathrm{mAb58} 8^{\prime} \mathrm{Cl}$. As with the previously described mAbs, tigatuzumab convinced with promising preclinical results, including pancreatic cancer cell lines and murine PDAC xenografts [129-134]. In a phase I trial, tolerability was verified, and antitumor effects seemed to emerge, indicated by the high number of patients with stable disease [135]. A phase II study examining the combination of tigatuzumab and gemcitabine in patients with unresectable or metastatic pancreatic cancer was conducted [136]. In a nutshell, the results of the study were comparable to those of previous studies using gemcitabine monotherapy or in combination with other agents, given an overall survival of 8.2 months [136].

However, the underlying explanation for the clinical failure of TRAIL-R specific antibodies might be found in their mode of action. Since TRAIL engages TRAIL receptors as trimers, stimulation by bivalent antibodies results in stimulation of only two DRs and consequently in inadequate DISC formation reviewed in [46,137]. Moreover, it was uncovered that TRAIL-R1 becomes activated by membrane-bound TRAIL (memTRAIL) and soluble TRAIL (sTRAIL) whereas TRAIL-R2 is only activatable by memTRAIL or antibody-crosslinked sTRAIL [138]. Consequently, the capacity of TRAIL-R antibodies to induce apoptosis in pancreatic cancer might be feeble. In addition, tumor perfusion might represent a PDAC-specific problem [139-141]. Furthermore, the efficacy of recombinant antibodies directed against antigens on cancer cells relies on antibody-dependent, 
cell-mediated cytotoxicity (ADCC). Activatory and inhibitory fragment crystallizable $(\mathrm{Fc}) \gamma$ receptors (Fc $\gamma$ Rs) on immune cells regulate ADCC by binding to the $\mathrm{Fc}$ portion of immunoglobulins reviewed in [142]. The antitumor effect of the agonistic TRAIL-R2 antibody drozitumab was shown to be dependent on Fc $\gamma$ R-mediated clustering [143]. These data suggest that for the general in vivo efficiency of agonistic TRAIL-R antibodies cross-linking is crucial.

Potential interference of TRAIL-R-specific antibodies and endogenous TRAIL might also exist, competing for receptor binding. Intriguingly, dulanermin, the recombinant ligand, and AMG-655, both unsuccessful in clinical studies with the view of their antitumor efficiency, were demonstrated to synergize in killing TRAIL-resistant melanoma cells and also to increase antitumor activity in vivo. The combination of the substances provoked higher-order clustering of TRAIL-R2 thereby intensifying DISC formation $[144,145]$. Whether this effect also holds true for pancreatic cancer remains to be shown.

\subsection{Dysfunctional TRAIL-Induced Apoptosis in Pancreatic Cancer}

Even though anticancer effects of TRAIL in a variety of cancer cell lines has been demonstrated [34, 35], many primary tumor cells are inherently resistant to TRAIL-induced apoptosis [146]. These cells exploit mechanisms to circumvent death ligand-mediated apoptosis $[104,147,148]$, which are not entirely understood to date. The decision to live or die is taken at the level of pro and-antiapoptotic protein ratio in any cell. Notably, TRAIL-induced apoptosis can be inhibited at every step along the cascade by their respective anti-apoptotic proteins namely DcRs, c-FLIP-isoforms, and anti-apoptotic members of the Bcl-2-family such as Bcl-2 and Bcl-XL, and inhibitors of apoptosis proteins (IAPs) (Figure 2) [149]. Consequently, there are several possible mechanisms for tumor cells to harbor or acquire TRAIL resistance. PDAC cells exhibit resistance to TRAIL-induced apoptosis, primarily a result of constitutively up-regulated anti-apoptotic proteins such as c-FLIP, TNF receptor-associated factor 2 (TRAF2), Bcl-XL, and XIAP [103,150,151].

A study identified low expression of $O$-glycosylation $(\mathrm{O}$-glyc) genes as further potent mechanism contributing to TRAIL resistance. In PDAC inter alia, a correlation of the peptidyl $O$-glycosyltransferase GALNT14 mRNA expression with TRAIL sensitivity attracted attention. O-glyc of TRAIL-R2 triggers ligand-mediated clustering of the receptors and consequent recruitment and activation of caspase-8 [152]. Recent results demonstrate the enhancing effects on TRAIL-induced apoptosis mediated by $N$-glycosylation (N-glyc) of TRAIL-R1 while TRAIL-R2 is deficient of $N$-glyc sites. Dysfunction of apoptotic signaling was connected with $N$-glyc-deficient TRAIL-R1 resulting in lower receptor aggregation and reduced DISC formation [153]. These data suggest a different promotion of apoptosis by these two receptors since TRAIL-R1 is $N$-glycosylated and TRAIL-R2 is O-glycosylated.

The capability to induce apoptosis is reserved for TRAIL-R1 and TRAIL-R2 $[5,47,50]$. An imbalance between expression levels of non-cell-death-inducing and cell death-inducing TRAIL-Rs might influence apoptosis signaling [51-55]. The truncated death domain of TRAIL-R4 induces nuclear factor kappa light chain enhancer of activated B cells (NF- $\mathrm{kB})$, a transcription factor complicit in pro-inflammatory immune responses, presenting protection against apoptosis $[104,154]$. NF- $\mathrm{KB}$ was found to be constitutively active in pancreatic cancer cells resulting in elevated levels of XIAP thereby preventing apoptosis $[104,155]$. Expression of anti-apoptotic proteins such as TRAF2 and c-FLIP is also connected with the activation of NF-KB [156,157]. Furthermore, it was demonstrated that TRAIL-R4 forms heterotrimers with TRAIL-R2 to build ligand-independent inactive structures to prevent apoptosis or initiate gene-activating pathways such as NF-kB-mediated ones $[45,154]$. Death- and survival pathways can be switched in clonal populations of cancer cells in response to the treatment. The result is 'fractional killing' of the parental cellular population, while the surviving resistant fraction is selected. This 'fractional killing' by therapeutics is not only stem-cell dependent, however, significant variability can also arise from natural alterations in protein levels [158]. In this context, it was revealed that TRAIL-R2 plays an independent dual role in simultaneously mediated pro-apoptotic and pro-survival signaling [159]. 


\subsection{TRAIL-Mediated Non-Canonical Signaling}

In recent years, it has become evident that above and beyond the classical route of apoptosis induction, TRAIL can trigger alternative non-cell death pathways (Figure 3). The induction of NF-KB [65,104,154,160], mitogen-activated protein kinase (MAPK) [161], tyrosine kinase Rous sarcoma oncogene cellular homolog (SRC) and (phosphoinositide 3-kinase (PI3K) pathways [162,163] has been described. TRAIL-induced protein kinase B (AKT) signaling, has been confirmed in numerous cancer entities. AKT is a PI3K-activated protein kinase which is primarily involved in cellular functions like cell growth, survival, and apoptosis. Stimulation of AKT signaling might also play its part in the development of TRAIL-resistance since inhibition of the pathway sensitized initial TRAIL-resistant lung, breast or ovarian cancer cells to TRAIL-induced apoptosis [164-166].

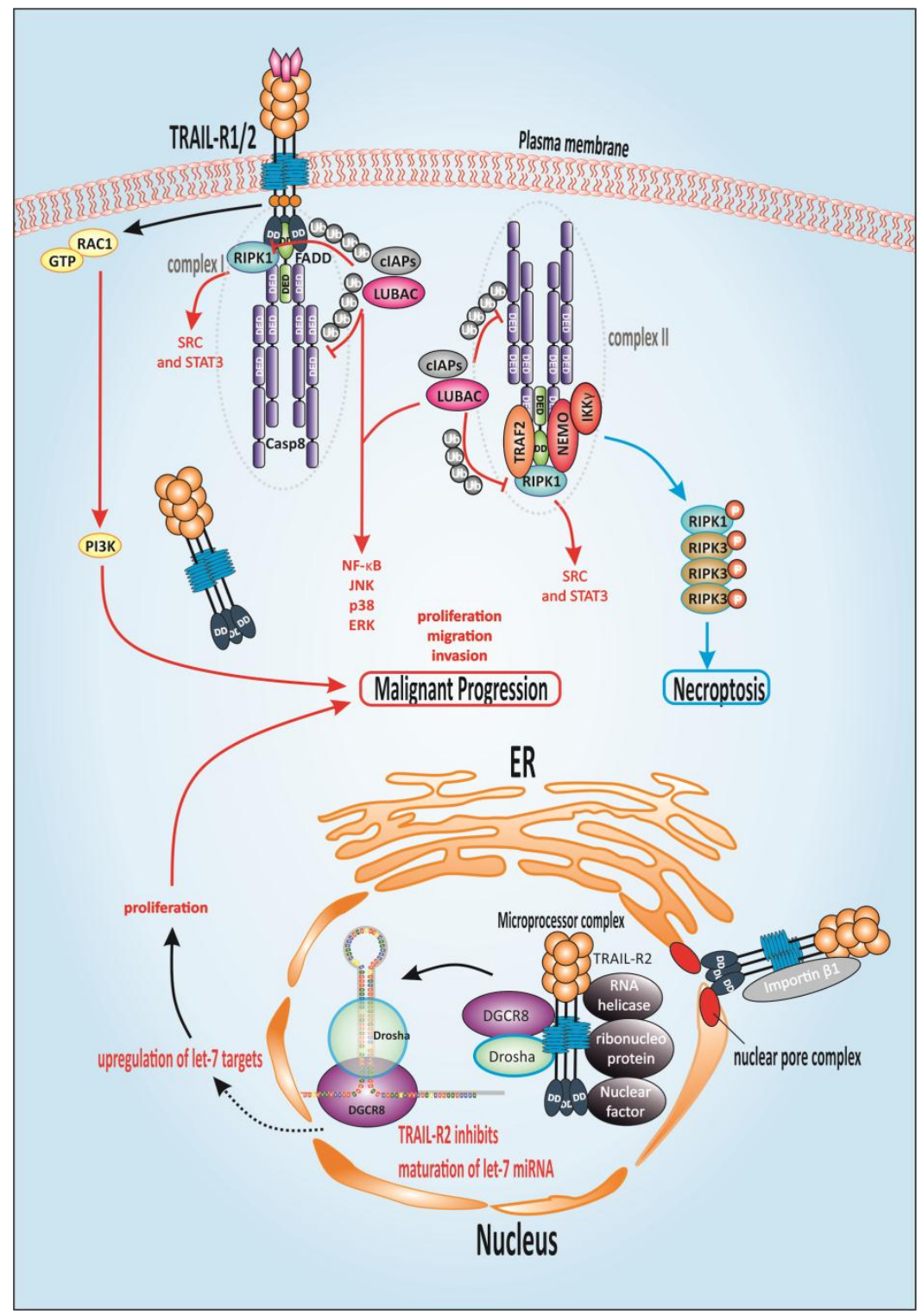

Figure 3. TRAIL-mediated non-apoptotic signaling. TRAIL binding induces assembly of a second cytosolic complex, retaining TNF superfamily receptor 6 (Fas)-associated death domain (FADD) and caspase-8 and recruiting receptor-interacting protein kinase 1 (RIPK1), tumor necrosis factor (TNF) receptor-associated factor 2 (TRAF2), and nuclear factor kappa light chain enhancer of activated B cells (NF-kB) essential modifier (NEMO). Downstream of caspase-8, TRAF2 recruits cellular inhibitor of apoptosis protein $1 / 2$ (cIAP1/2) which in turn leads to the ubiquitination of RIPK1 and therefore 
recruitment linear ubiquitin chain assembly complex (LUBAC), that attaches linear poly-ubiquitin chains on RIPK1 [167]. RIPK1 is compulsory for the stimulation of tyrosine-protein kinase Rous sarcoma oncogene cellular homolog (SRC) and signal transducer and activator of transcription 3 (STAT3) which are responsible for pushing migration and invasion. Complex I and complex II trigger NF-kB, p38 mitogen-activated protein kinase (p38 MAPK), JUN N-terminal kinase (JNK) and extracellular signal-regulated kinase (ERK). LUBAC acts in both complexes, alleviating caspase-8 activation and enabling recruitment of the Inhibitor of $\mathrm{KB}(\mathrm{I} \kappa \mathrm{B})$ kinase (IKK) complex, and consequently activation of NF- $\mathrm{KB}$. In case of inhibited caspase activation, the necrosome is built by the interaction of RIPK1 and RIPK3. Independently of FADD and complex I and II, the membrane-proximal domain (MPD) of TRAIL receptor 2 (TRAIL-R2) induces Rat sarcoma (Ras)-related C3 botulinum toxin substrate 1 (Rac1) activation to promote migration and invasion. TRAIL-R2 is also present in the nucleus and interacts with ribonucleoprotein complexes attributed to the maturation of microRNAs (miRNAs) of the let-7 family which interact with and inhibit mRNAs of various regulators of mitogenic pathways such as Ras and avian myelocytomatosis virus oncogene cellular homolog (c-Myc) thereby promoting proliferation. DD: death domain; DED: death effector domain; ER: endoplasmic reticulum; GTP: guanosine-5'-triphosphate; Ub: ubiquitin; DGCR8: DiGeorge critical region 8; P: phosphorylated.

Execution of these non-apoptotic, gene-activating pathways is cell-type dependent and occurs when apoptosis induction is prevented or as a result of 'fractional survival' in clonal populations of cancer cells. Besides the TRAIL-dependent pro-inflammatory, proliferation, and pro-survival functions of these noted pathways, migration- and invasion-enhancing effects have also been described [159,168-172]. Proliferation-enhancing and migration-promoting effects were found upon administration of exogenous TRAIL $[169,171]$. These findings enabled the description of a pro-invasive character of endogenous TRAIL in Kirsten rat sarcoma viral oncogene homolog (KRAS)-mutated cells. In murine models of KRAS-driven precursor lesions and metastasizing PDAC, deletion of mTRAIL-R led to the reduction of tumor growth and metastases, and prolonged mouse survival by constraining cancer cell-autonomous proliferation, migration, and invasion events. Moreover, high TRAIL-R2 expression related to lymph node invasion in human PDAC. Enhanced migration and invasion were attributed to activation of the Rat sarcoma (Ras)-related C3 botulinum toxin substrate 1 (Rac1)/PI3K pathway, mediated by constitutive TRAIL-R2 signals. Therefore, cancer cell-expressed endogenous TRAIL-R2 can promote PDAC throughout different stages. Of note, the signaling pathway was not mediated by the DD of TRAIL-R2, but its membrane-proximal domain (MTD) was necessary [170].

The induction of gene-activating pathways by TRAIL is supposed to be communicated via a second cytosolic complex (Figure 3), retaining DISC components FADD and caspase-8 but additionally recruiting receptor-interacting protein kinase 1 (RIPK1), TRAF2 and NF- $\mathrm{KB}$ essential modifier (NEMO)/inhibitor of $\mathrm{\kappa B}(\mathrm{I} \mathrm{KB}$ ) kinase (IKK) [173-175]. Downstream of caspase-8, TRAF2 is essential for cIAP1/2 recruitment, which in turn leads to the ubiquitination of RIPK1 with K11- and K63-linked poly-ubiquitin chains [176]. Ubiquitinated RIPK1 builds the platform for recruitment of linear ubiquitin chain assembly complex (LUBAC), an ubiquitin E3 ligase complex that attaches linear poly-ubiquitin chains on RIPK1 [167]. LUBAC acts in both complexes, alleviating caspase-8 activation and enabling recruitment of the IKK complex, and consequently activation of NF- $\mathrm{KB}[167,175,177]$.

So far, most known functions of TRAIL receptors are attributed to their presence at the plasma membrane. Nonetheless, high levels of intracellular TRAIL-R1/R2 are characteristic features for many tumors $[178,179]$ and little tangible knowledge is available about the function of repeatedly observed nuclear TRAIL-R2 (nTRAIL-R2) [180-182]. Thus, nTRAIL-R2 was found to interact with the Microprocessor complex and its accessory proteins. By this interaction, nTRAIL-R2 negatively regulated the maturation of miRNA let-7, which in turn is a known negative regulator of the expression of various proliferation-driving proteins like high-mobility group AT-hook 2 (HMGA2), Ras and avian myelocytomatosis virus oncogene cellular homolog (c-Myc) $[183,184]$. As a consequence, by inhibiting let-7-maturation, nTRAIL-R2 enhanced tumor cell proliferation [185]. 


\subsection{Alternative TRAIL-Mediated Death Signaling}

Besides the induction of non-cell death signaling, TRAIL-Rs have been shown to induce an alternative cell death pathway termed necroptosis reviewed in [186] (Figure 3). Necroptosis is promoted by RIPK1 and RIPK3 $[187,188]$. In case of inhibited caspase- 8 activity, apoptosis induction is prevented and building of the necrosome promoted by interaction of RIPK1 and RIPK3 [189,190]. Necroptosis can be blocked by pharmacological inhibition of the kinase activity of RIPK1 by necrostatin [190,191]. Interestingly, high levels of RIPK1 and RIPK3 have been described for PDAC, as well as their upregulation following treatment with gemcitabine. When the necrosome was blocked, pro-cancer effects have been observed in PDAC cells. Importantly, in vivo no oncogenic progression was detectable when RIP1 or RIP3 were inhibited [192], indicating that alternative anticancer pathways were activated. Deletion of RIPK3 might function in an anti-oncogenic manner via improved peri-tumoral immunogenicity. Since intrinsic resistance against TRAIL-induced apoptosis markedly affects treatment response, the capacity of TRAIL-Rs to mediate further cell-death signaling pathways contributes decisively to the extension of TRAIL-comprising treatment strategies. Particularly, regarding clinical approaches, these discoveries illustrate the urgent priority to gain knowledge on the orchestration of all TRAIL-induced signaling pathways, which might enable the prediction of therapy response and risk evaluation in respect to the promotion of the disease.

\section{Concluding Remarks and Future Perspectives}

Since PDAC is amongst the deadliest of solid tumors, it has become a paradigm for an almost incurable malignancy in today's research era. PDAC is mostly resistant to conventional therapy. Thus, the discovery of TRAIL created new hope for an alternative anticancer approach. Inducing extrinsic apoptosis, pharmacological targeting of TRAIL-Rs offers the possibility to circumvent resistance against intrinsic apoptosis, a pathway almost invariably inactivated through the loss or mutation of the tumor suppressor p53. However, the majority of primary PDAC cells are resistant or acquire resistance also to TRAIL-induced apoptosis. However, so far apart from promising preclinical studies, with none of the reviewed TRAIL-R agonists a therapeutic advantage in cancer patients has been reported [30]. Presumably, due to inherent TRAIL resistance, the insufficient potency of the used agonist, and a lack of biomarkers for patient stratification, the trials failed to achieve antitumor efficacy. Furthermore, it has emerged that physiological levels of TRAIL can signal so much more than mere apoptosis, which can provoke undesirable effects in the context of anticancer therapy.

Since tagged variants of recombinant TRAIL-induced hepatotoxicity, the untagged version dulanermin reached clinical testing. The plain fact that hrTRAIL failed to reveal any anticancer activity in various other tumor entities suggests that clinical trials with dulanermin in PDAC would also be unsatisfying. Since TRAIL-R1 was shown to promote apoptosis in PDAC whereas TRAIL-R2 induced pro-inflammatory cytokines, a PDAC trial would be more likely to benefit from a TRAIL-R1-selective treatment [59].

Although it is far too early to find a conclusive answer to the question 'Should we keep walking along the TRAIL for pancreatic cancer treatment?', several trial options are unexplored, for example TRAIL-R1 selective targeting which surely should be tested. However, selective approaches need to be intensively studied, since recent results demonstrate the dual role of a single TRAIL-R in not only mediating apoptosis but also stimulating non-apoptotic pathways, supporting 'fractional survival' [159]. Most importantly, sensitizing strategies to overcome TRAIL resistance [51,193,194] and crosslinked TRAIL-R agonists, ensuring clustering of TRAIL-Rs intensifying DISC formation might be steps towards successful TRAIL therapy. This approach can be enhanced by combination with tagged TRAIL $[45,195]$, to extend half-life period and stability, and to combine TRAIL with agents sensitizing to TRAIL-induced apoptosis [145]. However, restricted drug bioavailability in PDAC caused by reduced perfusion [140] and desmoplastic stroma needs to be conquered. The hopeful outcomes of the in vivo testing of some of the described new TRAIL formulations must be further verified over the next years (i) in a broader spectrum of tumor entities with special attention to mutations and predictive 
markers, and in (ii) more complex models, representing the heterogeneity and microenvironment of tumors in a manner closer to reality.

Based on the limited activity of TRAIL-R agonists discussed above, the design of new TRAIL-R agonists aimed at higher potency to induce apoptosis via TRAIL-R1 and TRAIL-R2 [196]. One of these agents, firstly reaching clinical testing, was TAS266, an agonistic tetravalent nanobody directed against TRAIL-R2 [197]. Nanobody approaches can overcome limitations of the efficiency of mAbs in distribution and tumor penetration. Characteristics of variable fragments of Camelid heavy-chain-only antibodies (HcAbs), termed nanobodies, comprise their small size, chemical and thermal stability, high solubility, specificity and affinity, and their simplicity of cloning, as reviewed in [198]. TAS266 is assembled from four identical humanized high-affinity heavy chain domain (VHH) antibody fragments. Since TRAIL-R2 can be engaged by each VHH domain with high affinity, simultaneously clustering of four receptor molecules is possible, therefore intensifying DISC formation. The data obtained revealed that higher valency of DR5 binding correlates with the increased velocity of caspase induction in vitro [197]. However, clinical testing of the substance had to be prematurely terminated, because patients suffered from unexpected symptoms of hepatotoxicity. The underlying mechanisms can only be presumed, including the agent's immunogenicity and enhanced potency [199]. Therefore, potentially expected immune reactions need to be evaluated extensively preceding de novo clinical testing.

Efficient cell-death induction by agonistic anti-TRAIL-R antibodies can only be gained due to high clustering capacity. A new class of TRAIL-R agonists possesses this characteristic as it comprises three TRAIL-promoter subsequences united in one polypeptide chain, defined as single-chain-TRAIL-receptor-binding domain (scTRAIL-RBD). Two scTRAIL-RBDs and three receptor binding sites are fused to a protein with hexavalent binding capacity. APG350, the prototype of this approach was created by merging the Fc-part of human IgG1 and the scTRAIL-RBD polypeptide which is thereby able to bind simultaneously six TRAIL-receptors (TRAIL-R1 and TRAIL-R2) per drug molecule. Moreover, APG350 exerts high antitumor potential and induces superior clustering independent of Fc $\gamma$ R-mediated cross-linking [200]. Circularly permuted TRAIL (CPT) is a further recombinant version of human TRAIL and is currently clinical investigated for the treatment of hematologic malignancies [201-203]. In comparison to wild-type TRAIL, CPT is constructed by the $N$-terminus of amino acid 121-135 sequence of TRAIL and the C-terminus of the amino acid 135-281 sequence of TRAIL connected via a flexible linker. The substance engages TRAIL-R1 and TRAIL-R2 as stable homotrimers and exhibits higher stability and at least improved half-life than wild-type TRAIL [204]. In a single dose-escalation study, no toxicity and maximum tolerated dose was detectable [201]. Depending on the missing preference for one apoptosis-inducing TRAIL-R, the molecule might be effective for PDAC treatment.

Since TRAIL resistance is a severe obstacle, numerous sensitizing strategies in TRAIL-signaling have been envisaged. These may ultimately prevent adverse TRAIL-signaling output on the one hand, and efficiently target PDAC in the future by efficiently inducing apoptosis on the other. Some promising examples of these strategies are described as the substances are already clinically used and are well-described: The herbal anticancer drug paclitaxel enhances TRAIL efficiency for example in gastric cancer cells and prostate cancer stem cells [205,206]. TRAIL-embedded paclitaxel-bound albumin nanoparticles were sufficient in PDAC xenografts [207]. A further plant-derived, cell cycle inhibiting compound, benzyl isothiocyanate (BITC) sensitized KRAS-mutated PDAC cells to TRAIL-induced apoptosis [208] and the natural occurring steroidal lactone, withanolide E, and TRAIL cooperate in various human cancer cells by degradation of c-FLIP [209]. Amplification of TRAIL-induced apoptosis was also attributed to the anti-diabetic drug metformin in colorectal cancer cells [210] and to bortezomib by inhibition of the proteasome [211]. Since PDAC is preclinical responsive to histone deacetylase (HDAC) inhibitors [212,213], this approach might also contribute to overcome TRAIL-resistance in pancreatic cancer as shown for multiple myeloma cells and breast cancer cells $[214,215]$. The intrinsic apoptosis pathway is controlled by the Bcl-2 protein family resulting in cytochrome c release and subsequent activation of downstream caspases. Crosstalk between the two apoptotic pathways can 
influence cell death induction. The raised expression of anti-apoptotic proteins such as Bcl-2 and $\mathrm{Bcl}-\mathrm{XL}$, can constrain the activation of the intrinsic apoptosis pathway and provoke resistance to anti-cancer therapeutics, including TRAIL. Navitoclax (ABT-263) a Bcl-2/Bcl-XL selective inhibitor was reported to sensitize PDAC cells to TRAIL [216]. Moreover, TRAIL resistance can be strikingly overcome by the use of IAP antagonists or SMAC mimetics $[217,218]$ or simultaneous pharmacological inhibition of cyclin-dependent kinase 9 (CDK9), resulting in suppression of anti-apoptotic c-FLIP and Mcl-1 [193].

The lack of predictive biomarkers for TRAIL treatment response is likely to be a significant contributing factor that the potential of TRAIL in a convenient clinical setting is not assessable. In a study to identify mediators of TRAIL-sensitivity in various tumor cell lines, among other things in PDAC, the molecule most significantly correlating with response to dulanermin was $\mathrm{N}$-acetylgalactosaminyltransferase-14 (GALNT14), responsible for receptor glycosylation and clustering [152]. However, so far, GALNT14 was not clinically proven in pancreatic cancer [219] but might be convenient for prediction of response to death receptor agonists in this setting.

Additionally, intensified knowledge in orchestrated mechanisms of TRAIL-TRAIL-R-signaling, especially in KRAS-mutated PDAC [170], would present a further approach towards targeted therapy. Since the endogenous TRAIL-TRAIL-R-system promotes KRAS-mutated tumor growth, invasion and metastases in PDAC, future therapeutic strategies seeking to harness TRAIL's apoptosis-inducing activity should aim to block this unwanted pro-tumorigenic effect and in turn boost TRAIL-induced pro-apoptotic pathways.

Acknowledgments: This work was funded by a research fellowship from the University of Ulm (Bausteinprogramm 3.2) given to J.L. S.v.K. is funded through the Max-Eder-Programme of the German Cancer Aid. A.T. is supported by German Cancer Aid.

Author Contributions: J.L., D.H.-B. and S.v.K. designed the study. A.-L.K., A.H. and S.v.K. performed the literature search. A.-L.K. and J.L. prepared the figures. A.-L.K., S.v.K., A.H., U.K. and A.T. wrote the manuscript. All authors contributed to the preparation of the manuscript. All authors read and approved the manuscript.

Conflicts of Interest: All authors declare no conflict of interest.

\section{Abbreviations}

$\begin{array}{ll}\text { 5-FU } & \text { 5-fluorouracil } \\ \text { ADCC } & \text { antibody-dependent cellular cytotoxicity } \\ \text { AKT } & \text { protein kinase B } \\ \text { ATM } & \text { mutated in the disease ataxia telangiectasia } \\ \text { ATP } & \text { adenosine triphosphate } \\ \text { Apo2L } & \text { Apo-2 ligand } \\ \text { Bak } & \text { Bcl-2 antagonist or killer } \\ \text { Bax } & \text { Bcl-2-associated X protein } \\ \text { Bcl-2 } & \text { B-cell CLL/lymphoma 2 } \\ \text { Bcl-XL } & \text { B-cell lymphoma-extra-large } \\ \text { BH3 } & \text { Bcl-2 homology domain 3 } \\ \text { Bid } & \text { BH3-only protein } \\ \text { BITC } & \text { benzyl isothiocyanate } \\ \text { CDK9 } & \text { cyclin-dependent kinase 9 } \\ \text { c-FLIP } & \text { cellular (FADD-like IL-1 } 3 \text {-converting enzyme)-inhibitory protein } \\ \text { cIAP } & \text { cellular IAP } \\ \text { c-Myc } & \text { avian myelocytomatosis virus oncogene cellular homolog } \\ \text { DcR } & \text { decoy receptor } \\ \text { CPT } & \text { circularly permuted TRAIL } \\ \text { DD } & \text { death domain } \\ \text { DDR } & \text { DNA damage response } \\ \text { DGCR8 } & \text { DiGeorge critical region8 }\end{array}$




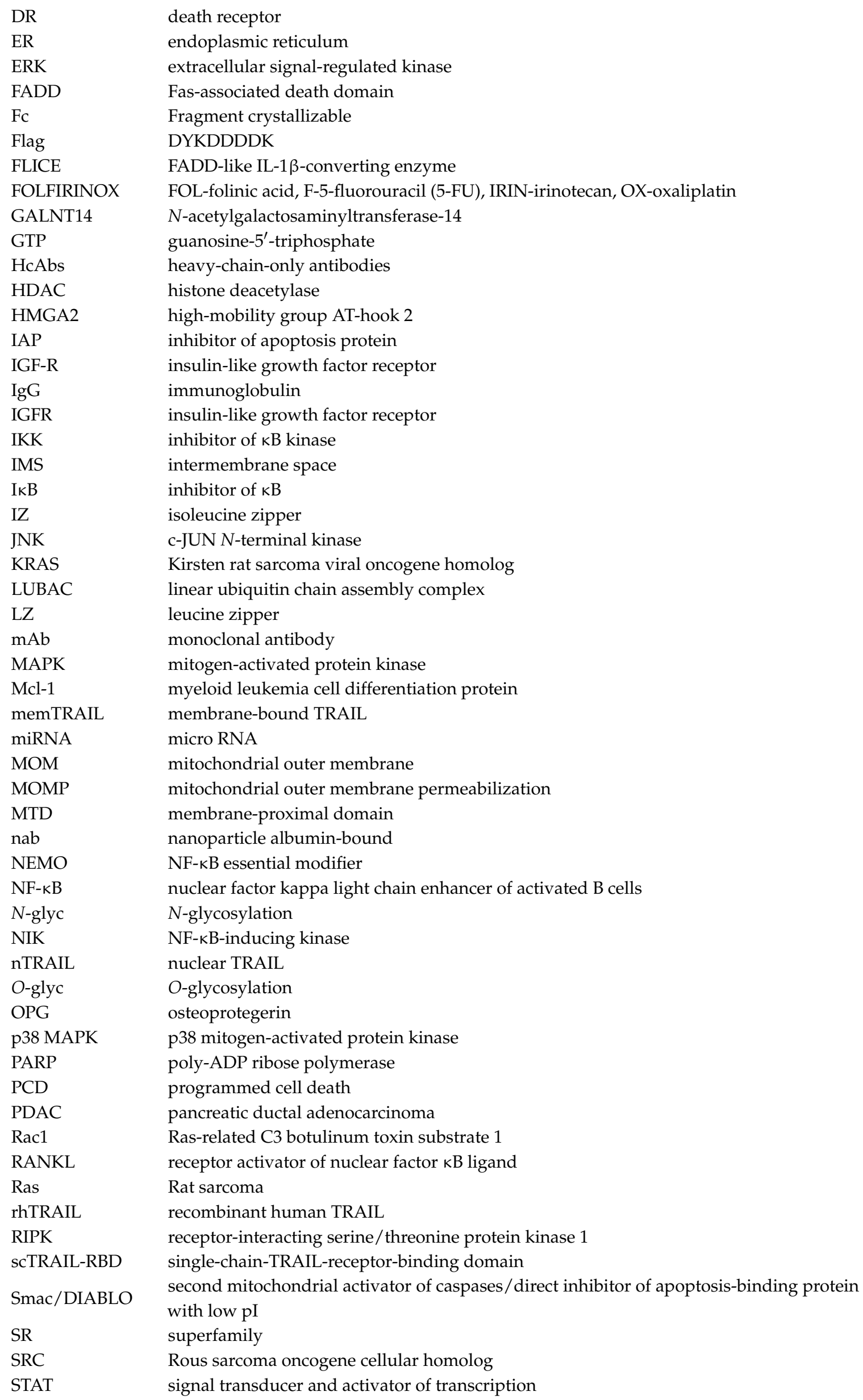




$\begin{array}{ll}\text { sTRAIL } & \text { soluble TRAIL } \\ \text { TNF } & \text { tumor necrosis factor } \\ \text { TAPE } & \text { threonine, alanine, proline, glutamine } \\ \text { TRAIL } & \text { TNF-related apoptosis-inducing ligand } \\ \text { TRAIL-R } & \text { Trail receptor } \\ \text { Ub } & \text { ubiquitin } \\ \text { VHH } & \text { heavy chain domain } \\ \text { XIAP } & \text { X-linked inhibitor of apoptosis protein }\end{array}$

\section{References}

1. Hanahan, D.; Weinberg, R.A. The hallmarks of cancer. Cell 2000, 100, 57-70. [PubMed]

2. Hanahan, D.; Weinberg, R.A. Hallmarks of cancer: The next generation. Cell 2011, 144, 646-674. [PubMed]

3. Westphal, S.; Kalthoff, H. Apoptosis: Targets in pancreatic cancer. Mol. Cancer 2003, 2, 6. [PubMed]

4. Johnstone, R.W.; Ruefli, A.A.; Lowe, S.W. Apoptosis: A link between cancer genetics and chemotherapy. Cell 2002, 108, 153-164. [PubMed]

5. Ashkenazi, A. Targeting death and decoy receptors of the tumour-necrosis factor superfamily. Nat. Rev. Cancer 2002, 2, 420-430. [PubMed]

6. Wallace-Brodeur, R.R.; Lowe, S.W. Clinical implications of p53 mutations. Cell. Mol. Life Sci. 1999, 55, 64-75. [CrossRef] [PubMed]

7. Lemke, J.; von Karstedt, S.; Zinngrebe, J.; Walczak, H. Getting TRAIL back on track for cancer therapy. Cell Death Differ. 2014, 21, 1350-1364. [CrossRef] [PubMed]

8. Ghosh, S.K. Giovanni Battista Morgagni (1682-1771): Father of pathologic anatomy and pioneer of modern medicine. Anat. Sci. Int. 2017, 92, 305-312. [CrossRef] [PubMed]

9. Ferlay, J.; Soerjomataram, I.; Ervik, M.; Dikshit, R.; Eser, S.; Mathers, C.; Rebelo, M.; Parkin, D.M.; Forman, D.; Bray, F. GLOBOCAN 2012 v1.0, Cancer Incidence and Mortality Worldwide: IARC CancerBase No. 11 [online]. 2012; International Agency for Research on Cancer: Lyon, France, 2013.

10. Hamacher, R.; Schmid, R.M.; Saur, D.; Schneider, G. Apoptotic pathways in pancreatic ductal adenocarcinoma. Mol. Cancer 2008, 7, 64. [PubMed]

11. He, J.; Ahuja, N.; Makary, M.A.; Cameron, J.L.; Eckhauser, F.E.; Choti, M.A.; Hruban, R.H.; Pawlik, T.M.; Wolfgang, C.L. 2564 resected periampullary adenocarcinomas at a single institution: Trends over three decades. HPB (Oxford) 2014, 16, 83-90. [CrossRef] [PubMed]

12. Welsch, T.; Kleeff, J.; Friess, H. Molecular pathogenesis of pancreatic cancer: Advances and challenges. Curr. Mol. Med. 2007, 7, 504-521. [CrossRef] [PubMed]

13. Lemke, J.; Schafer, D.; Sander, S.; Henne-Bruns, D.; Kornmann, M. Survival and prognostic factors in pancreatic and ampullary cancer. Anticancer Res. 2014, 34, 3011-3020. [PubMed]

14. Kleeff, J.; Korc, M.; Apte, M.; La Vecchia, C.; Johnson, C.D.; Biankin, A.V.; Neale, R.E.; Tempero, M.; Tuveson, D.A.; Hruban, R.H.; et al. Pancreatic cancer. Nat. Rev. Dis. Primers 2016, 2, 16022. [CrossRef] [PubMed]

15. Hidalgo, M. Pancreatic cancer. New Engl. J. Med. 2010, 362, 1605-1617. [CrossRef] [PubMed]

16. Burris, H.A., 3rd; Moore, M.J.; Andersen, J.; Green, M.R.; Rothenberg, M.L.; Modiano, M.R.; Cripps, M.C.; Portenoy, R.K.; Storniolo, A.M.; Tarassoff, P.; et al. Improvements in survival and clinical benefit with gemcitabine as first-line therapy for patients with advanced pancreas cancer: A randomized trial. J. Clin. Oncol. 1997, 15, 2403-2413. [CrossRef] [PubMed]

17. Plunkett, W.; Huang, P.; Xu, Y.Z.; Heinemann, V.; Grunewald, R.; Gandhi, V. Gemcitabine: Metabolism, mechanisms of action, and self-potentiation. Semin. Oncol. 1995, 22 (Suppl. 11), 3-10. [PubMed]

18. Conroy, T.; Desseigne, F.; Ychou, M.; Bouché, O.; Guimbaud, R.; Bécouarn, Y.; Adenis, A.; Raoul, J.-L.; Gourgou-Bourgade, S.; de la Fouchardière, C.; et al. FOLFIRINOX versus Gemcitabine for Metastatic Pancreatic Cancer. New Engl. J. Med. 2011, 364, 1817-1825. [CrossRef] [PubMed]

19. Von Hoff, D.D.; Ervin, T.; Arena, F.P.; Chiorean, E.G.; Infante, J.; Moore, M.; Seay, T.; Tjulandin, S.A.; Ma, W.W.; Saleh, M.N.; et al. Increased survival in pancreatic cancer with nab-paclitaxel plus gemcitabine. New Engl. J. Med. 2013, 369, 1691-1703. [CrossRef] [PubMed] 
20. Lee, H.S.; Park, S.W. Systemic Chemotherapy in Advanced Pancreatic Cancer. Gut Liver 2016, 10, $340-347$. [CrossRef] [PubMed]

21. Saung, M.T.; Zheng, L. Current Standards of Chemotherapy for Pancreatic Cancer. Clin. Ther. 2017, 39, 2125-2134. [CrossRef] [PubMed]

22. Moran, R.G.; Keyomarsi, K. Biochemical rationale for the synergism of 5-fluorouracil and folinic acid. NCI Monogr. Publ. Natl. Cancer Inst. 1987, 5, 159-163.

23. Longley, D.B.; Harkin, D.P.; Johnston, P.G. 5-fluorouracil: Mechanisms of action and clinical strategies. Nat. Rev. Cancer 2003, 3, 330-338. [CrossRef] [PubMed]

24. Mathijssen, R.H.; Loos, W.J.; Verweij, J.; Sparreboom, A. Pharmacology of topoisomerase I inhibitors irinotecan (CPT-11) and topotecan. Curr. Cancer Drug Targets 2002, 2, 103-123. [PubMed]

25. Raymond, E.; Faivre, S.; Woynarowski, J.M.; Chaney, S.G. Oxaliplatin: Mechanism of action and antineoplastic activity. Semin. Oncol. 1998, 25 (Suppl. 5), 4-12. [PubMed]

26. Wani, M.C.; Taylor, H.L.; Wall, M.E.; Coggon, P.; McPhail, A.T. Plant antitumor agents. VI. The isolation and structure of taxol, a novel antileukemic and antitumor agent from Taxus brevifolia. J. Am. Chem. Soc. 1971, 93, 2325-2327. [CrossRef] [PubMed]

27. Hoffman, R.M. Nab-paclitaxel: A limited improvement under the current therapeutic paradigm of pancreatic cancer. Expert Opin. Pharmacother. 2015, 16, 943-947. [CrossRef] [PubMed]

28. Schiff, P.B.; Horwitz, S.B. Taxol stabilizes microtubules in mouse fibroblast cells. Proc. Natl. Acad. Sci. USA 1980, 77, 1561-1565. [CrossRef] [PubMed]

29. Faris, J.E.; Blaszkowsky, L.S.; McDermott, S.; Guimaraes, A.R.; Szymonifka, J.; Huynh, M.A.; Ferrone, C.R.; Wargo, J.A.; Allen, J.N.; Dias, L.E.; et al. FOLFIRINOX in locally advanced pancreatic cancer: The Massachusetts General Hospital Cancer Center experience. Oncologist 2013, 18, 543-548. [CrossRef] [PubMed]

30. Gunturu, K.S.; Yao, X.; Cong, X.; Thumar, J.R.; Hochster, H.S.; Stein, S.M.; Lacy, J. FOLFIRINOX for locally advanced and metastatic pancreatic cancer: Single institution retrospective review of efficacy and toxicity. Med. Oncol. 2013, 30, 361. [CrossRef] [PubMed]

31. Schniewind, B.; Christgen, M.; Kurdow, R.; Haye, S.; Kremer, B.; Kalthoff, H.; Ungefroren, H. Resistance of pancreatic cancer to gemcitabine treatment is dependent on mitochondria-mediated apoptosis. Int. J. Cancer 2004, 109, 182-188. [CrossRef] [PubMed]

32. Wiley, S.R.; Schooley, K.; Smolak, P.J.; Din, W.S.; Huang, C.P.; Nicholl, J.K.; Sutherland, G.R.; Smith, T.D.; Rauch, C.; Smith, C.A.; et al. Identification and characterization of a new member of the TNF family that induces apoptosis. Immunity 1995, 3, 673-682. [CrossRef]

33. Pitti, R.M.; Marsters, S.A.; Ruppert, S.; Donahue, C.J.; Moore, A.; Ashkenazi, A. Induction of apoptosis by Apo-2 ligand, a new member of the tumor necrosis factor cytokine family. J. Biol. Chem. 1996, 271, 12687-12690. [CrossRef] [PubMed]

34. Walczak, H.; Miller, R.E.; Ariail, K.; Gliniak, B.; Griffith, T.S.; Kubin, M.; Chin, W.; Jones, J.; Woodward, A.; Le, T.; et al. Tumoricidal activity of tumor necrosis factor-related apoptosis-inducing ligand in vivo. Nat. Med. 1999, 5, 157-163. [CrossRef] [PubMed]

35. Ashkenazi, A.; Pai, R.C.; Fong, S.; Leung, S.; Lawrence, D.A.; Marsters, S.A.; Blackie, C.; Chang, L.; McMurtrey, A.E.; Hebert, A.; et al. Safety and antitumor activity of recombinant soluble Apo2 ligand. J. Clin. Investig. 1999, 104, 155-162. [CrossRef] [PubMed]

36. Pan, G.; Ni, J.; Wei, Y.F.; Yu, G.; Gentz, R.; Dixit, V.M. An antagonist decoy receptor and a death domain-containing receptor for TRAIL. Science 1997, 277, 815-818. [CrossRef] [PubMed]

37. Walczak, H.; Degli-Esposti, M.A.; Johnson, R.S.; Smolak, P.J.; Waugh, J.Y.; Boiani, N.; Timour, M.S.; Gerhart, M.J.; Schooley, K.A.; Smith, C.A.; et al. TRAIL-R2: A novel apoptosis-mediating receptor for TRAIL. EMBO J. 1997, 16, 5386-5397. [CrossRef] [PubMed]

38. Kawakubo, T.; Okamoto, K.; Iwata, J.; Shin, M.; Okamoto, Y.; Yasukochi, A.; Nakayama, K.I.; Kadowaki, T.; Tsukuba, T.; Yamamoto, K. Cathepsin E prevents tumor growth and metastasis by catalyzing the proteolytic release of soluble TRAIL from tumor cell surface. Cancer Res. 2007, 67, 10869-10878. [CrossRef] [PubMed]

39. Hymowitz, S.G.; Christinger, H.W.; Fuh, G.; Ultsch, M.; O'Connell, M.; Kelley, R.F.; Ashkenazi, A.; de Vos, A.M. Triggering cell death: The crystal structure of Apo2L/TRAIL in a complex with death receptor 5. Mol. Cell 1999, 4, 563-571. [CrossRef] 
40. Mongkolsapaya, J.; Grimes, J.M.; Chen, N.; Xu, X.N.; Stuart, D.I.; Jones, E.Y.; Screaton, G.R. Structure of the TRAIL-DR5 complex reveals mechanisms conferring specificity in apoptotic initiation. Nat. Struct. Biol. 1999, 6, 1048-1053. [PubMed]

41. Cha, S.S.; Kim, M.S.; Choi, Y.H.; Sung, B.J.; Shin, N.K.; Shin, H.C.; Sung, Y.C.; Oh, B.H. 2.8 A resolution crystal structure of human TRAIL, a cytokine with selective antitumor activity. Immunity 1999, 11, $253-261$. [CrossRef]

42. Hymowitz, S.G.; O'Connell, M.P.; Ultsch, M.H.; Hurst, A.; Totpal, K.; Ashkenazi, A.; de Vos, A.M.; Kelley, R.F. A unique zinc-binding site revealed by a high-resolution X-ray structure of homotrimeric Apo2L/TRAIL. Biochemistry 2000, 39, 633-640. [CrossRef] [PubMed]

43. Mariani, S.M.; Matiba, B.; Armandola, E.A.; Krammer, P.H. Interleukin $1 \beta$-converting enzyme related proteases/caspases are involved in TRAIL-induced apoptosis of myeloma and leukemia cells. J. Cell Biol. 1997, 137, 221-229. [CrossRef] [PubMed]

44. Gibellini, D.; Borderi, M.; De Crignis, E.; Cicola, R.; Vescini, F.; Caudarella, R.; Chiodo, F.; Re, M.C. RANKL/OPG/TRAIL plasma levels and bone mass loss evaluation in antiretroviral naive HIV-1-positive men. J. Med. Virol. 2007, 79, 1446-1454. [CrossRef] [PubMed]

45. De Miguel, D.; Lemke, J.; Anel, A.; Walczak, H.; Martinez-Lostao, L. Onto better TRAILs for cancer treatment. Cell Death Differ. 2016, 23, 733-747. [CrossRef] [PubMed]

46. Von Karstedt, S.; Montinaro, A.; Walczak, H. Exploring the TRAILs less travelled: TRAIL in cancer biology and therapy. Nat. Rev. Cancer 2017, 17, 352-366. [CrossRef] [PubMed]

47. LeBlanc, H.N.; Ashkenazi, A. Apo2L/TRAIL and its death and decoy receptors. Cell Death Differ. 2003, 10, 66-75. [CrossRef] [PubMed]

48. Emery, J.G.; McDonnell, P.; Burke, M.B.; Deen, K.C.; Lyn, S.; Silverman, C.; Dul, E.; Appelbaum, E.R.; Eichman, C.; DiPrinzio, R.; et al. Osteoprotegerin is a receptor for the cytotoxic ligand TRAIL. J. Biol. Chem. 1998, 273, 14363-14367. [CrossRef] [PubMed]

49. Pan, G.; O’Rourke, K.; Chinnaiyan, A.M.; Gentz, R.; Ebner, R.; Ni, J.; Dixit, V.M. The receptor for the cytotoxic ligand TRAIL. Science 1997, 276, 111-113. [CrossRef] [PubMed]

50. Sheridan, J.P.; Marsters, S.A.; Pitti, R.M.; Gurney, A.; Skubatch, M.; Baldwin, D.; Ramakrishnan, L.; Gray, C.L.; Baker, K.; Wood, W.I.; et al. Control of TRAIL-induced apoptosis by a family of signaling and decoy receptors. Science 1997, 277, 818-821. [CrossRef] [PubMed]

51. Morizot, A.; Merino, D.; Lalaoui, N.; Jacquemin, G.; Granci, V.; Iessi, E.; Lanneau, D.; Bouyer, F.; Solary, E.; Chauffert, B.; et al. Chemotherapy overcomes TRAIL-R4-mediated TRAIL resistance at the DISC level. Cell Death Differ. 2011, 18, 700-711. [CrossRef] [PubMed]

52. Merino, D.; Lalaoui, N.; Morizot, A.; Schneider, P.; Solary, E.; Micheau, O. Differential inhibition of TRAIL-mediated DR5-DISC formation by decoy receptors 1 and 2. Mol. Cell. Biol. 2006, 26, 7046-7055. [CrossRef] [PubMed]

53. Neumann, S.; Hasenauer, J.; Pollak, N.; Scheurich, P. Dominant negative effects of tumor necrosis factor (TNF)-related apoptosis-inducing ligand (TRAIL) receptor 4 on TRAIL receptor 1 signaling by formation of heteromeric complexes. J. Biol. Chem. 2014, 289, 16576-16587. [CrossRef] [PubMed]

54. Vindrieux, D.; Reveiller, M.; Chantepie, J.; Yakoub, S.; Deschildre, C.; Ruffion, A.; Devonec, M.; Benahmed, M.; Grataroli, R. Down-regulation of DcR2 sensitizes androgen-dependent prostate cancer LNCaP cells to TRAIL-induced apoptosis. Cancer Cell Int. 2011, 11, 42. [CrossRef] [PubMed]

55. Aydin, C.; Sanlioglu, A.D.; Karacay, B.; Ozbilim, G.; Dertsiz, L.; Ozbudak, O.; Akdis, C.A.; Sanlioglu, S. Decoy receptor-2 small interfering RNA (siRNA) strategy employing three different siRNA constructs in combination defeats adenovirus-transferred tumor necrosis factor-related apoptosis-inducing ligand resistance in lung cancer cells. Hum. Gene Ther. 2007, 18, 39-50. [CrossRef] [PubMed]

56. Simonet, W.S.; Lacey, D.L.; Dunstan, C.R.; Kelley, M.; Chang, M.S.; Luthy, R.; Nguyen, H.Q.; Wooden, S.; Bennett, L.; Boone, T.; et al. Osteoprotegerin: A novel secreted protein involved in the regulation of bone density. Cell 1997, 89, 309-319. [CrossRef]

57. Takahashi, N.; Udagawa, N.; Suda, T. A new member of tumor necrosis factor ligand family, ODF/OPGL/TRANCE/RANKL, regulates osteoclast differentiation and function. Biochem. Biophys. Res. Commun. 1999, 256, 449-455. [CrossRef] [PubMed] 
58. Truneh, A.; Sharma, S.; Silverman, C.; Khandekar, S.; Reddy, M.P.; Deen, K.C.; McLaughlin, M.M.; Srinivasula, S.M.; Livi, G.P.; Marshall, L.A.; et al. Temperature-sensitive differential affinity of TRAIL for its receptors. DR5 is the highest affinity receptor. J. Biol. Chem. 2000, 275, 23319-23325. [CrossRef] [PubMed]

59. Lemke, J.; Noack, A.; Adam, D.; Tchikov, V.; Bertsch, U.; Roder, C.; Schutze, S.; Wajant, H.; Kalthoff, H.; Trauzold, A. TRAIL signaling is mediated by DR4 in pancreatic tumor cells despite the expression of functional DR5. J. Mol. Med. 2010, 88, 729-740. [CrossRef] [PubMed]

60. Stadel, D.; Mohr, A.; Ref, C.; MacFarlane, M.; Zhou, S.; Humphreys, R.; Bachem, M.; Cohen, G.; Moller, P.; Zwacka, R.M.; et al. TRAIL-induced apoptosis is preferentially mediated via TRAIL receptor 1 in pancreatic carcinoma cells and profoundly enhanced by XIAP inhibitors. Clin. Cancer Res. 2010, 16, 5734-5749. [CrossRef] [PubMed]

61. MacFarlane, M.; Kohlhaas, S.L.; Sutcliffe, M.J.; Dyer, M.J.; Cohen, G.M. TRAIL receptor-selective mutants signal to apoptosis via TRAIL-R1 in primary lymphoid malignancies. Cancer Res. 2005, 65, 11265-11270. [CrossRef] [PubMed]

62. MacFarlane, M.; Inoue, S.; Kohlhaas, S.L.; Majid, A.; Harper, N.; Kennedy, D.B.; Dyer, M.J.; Cohen, G.M. Chronic lymphocytic leukemic cells exhibit apoptotic signaling via TRAIL-R1. Cell Death Differ. 2005, 12, 773-782. [CrossRef] [PubMed]

63. Yu, R.; Albarenque, S.M.; Cool, R.H.; Quax, W.J.; Mohr, A.; Zwacka, R.M. DR4 specific TRAIL variants are more efficacious than wild-type TRAIL in pancreatic cancer. Cancer Biol. Ther. 2014, 15, 1658-1666. [CrossRef] [PubMed]

64. Mohr, A.; Yu, R.; Zwacka, R.M. TRAIL-receptor preferences in pancreatic cancer cells revisited: Both TRAIL-R1 and TRAIL-R2 have a licence to kill. BMC Cancer 2015, 15, 494. [CrossRef] [PubMed]

65. Chaudhary, P.M.; Eby, M.; Jasmin, A.; Bookwalter, A.; Murray, J.; Hood, L. Death receptor 5, a new member of the TNFR family, and DR4 induce FADD-dependent apoptosis and activate the NF- $\mathrm{KB}$ pathway. Immunity 1997, 7, 821-830. [CrossRef]

66. Wang, T.T.; Jeng, J. Coordinated regulation of two TRAIL-R2/KILLER/DR5 mRNA isoforms by DNA damaging agents, serum and $17 \beta$-estradiol in human breast cancer cells. Breast Cancer Res. Treat. 2000, 61, 87-96. [CrossRef] [PubMed]

67. Wu, G.S.; Burns, T.F.; Zhan, Y.; Alnemri, E.S.; El-Deiry, W.S. Molecular cloning and functional analysis of the mouse homologue of the KILLER/DR5 tumor necrosis factor-related apoptosis-inducing ligand (TRAIL) death receptor. Cancer Res. 1999, 59, 2770-2775. [PubMed]

68. Schneider, P.; Olson, D.; Tardivel, A.; Browning, B.; Lugovskoy, A.; Gong, D.; Dobles, M.; Hertig, S.; Hofmann, K.; Van Vlijmen, H.; et al. Identification of a new murine tumor necrosis factor receptor locus that contains two novel murine receptors for tumor necrosis factor-related apoptosis-inducing ligand (TRAIL). J. Biol. Chem. 2003, 278, 5444-5454. [CrossRef] [PubMed]

69. Bossen, C.; Ingold, K.; Tardivel, A.; Bodmer, J.L.; Gaide, O.; Hertig, S.; Ambrose, C.; Tschopp, J.; Schneider, P. Interactions of tumor necrosis factor (TNF) and TNF receptor family members in the mouse and human. J. Biol. Chem. 2006, 281, 13964-13971. [CrossRef] [PubMed]

70. Jacobson, M.D.; Weil, M.; Raff, M.C. Programmed cell death in animal development. Cell 1997, 88, 347-354. [CrossRef]

71. Kerr, J.F.; Wyllie, A.H.; Currie, A.R. Apoptosis: A basic biological phenomenon with wide-ranging implications in tissue kinetics. Br. J. Cancer 1972, 26, 239-257. [CrossRef] [PubMed]

72. Brune, W.; Andoniou, C.E. Die Another Day: Inhibition of Cell Death Pathways by Cytomegalovirus. Viruses 2017, 9, 249. [CrossRef] [PubMed]

73. Brenner, D.; Mak, T.W. Mitochondrial cell death effectors. Curr. Opin. Cell Biol. 2009, 21, 871-877. [CrossRef] [PubMed]

74. Favaloro, B.; Allocati, N.; Graziano, V.; Di Ilio, C.; De Laurenzi, V. Role of apoptosis in disease. Aging (Albany NY) 2012, 4, 330-349. [CrossRef] [PubMed]

75. Burke, P.J. Mitochondria, Bioenergetics and Apoptosis in Cancer. Trends Cancer 2017, 3, 857-870. [CrossRef] [PubMed]

76. Wang, S.; El-Deiry, W.S. TRAIL and apoptosis induction by TNF-family death receptors. Oncogene 2003, 22, 8628-8633. [CrossRef] [PubMed] 
77. Neureiter, D.; Jager, T.; Ocker, M.; Kiesslich, T. Epigenetics and pancreatic cancer: Pathophysiology and novel treatment aspects. World J. Gastroenterol. 2014, 20, 7830-7848. [CrossRef] [PubMed]

78. McCarthy, E.F. The Toxins of William B. Coley and the Treatment of Bone and Soft-Tissue Sarcomas. Iowa Orthop. J. 2006, 26, 154-158. [PubMed]

79. Carswell, E.A.; Old, L.J.; Kassel, R.L.; Green, S.; Fiore, N.; Williamson, B. An endotoxin-induced serum factor that causes necrosis of tumors. Proc. Natl. Acad. Sci. USA 1975, 72, 3666-3670. [CrossRef] [PubMed]

80. Roberts, N.J.; Zhou, S.; Diaz, L.A., Jr.; Holdhoff, M. Systemic use of tumor necrosis factor alpha as an anticancer agent. Oncotarget 2011, 2, 739-751. [CrossRef] [PubMed]

81. Trauth, B.C.; Klas, C.; Peters, A.M.; Matzku, S.; Moller, P.; Falk, W.; Debatin, K.M.; Krammer, P.H. Monoclonal antibody-mediated tumor regression by induction of apoptosis. Science 1989, 245, 301-305. [CrossRef] [PubMed]

82. Yonehara, S.; Ishii, A.; Yonehara, M. A cell-killing monoclonal antibody (anti-Fas) to a cell surface antigen co-downregulated with the receptor of tumor necrosis factor. J. Exp. Med. 1989, 169, 1747-1756. [CrossRef] [PubMed]

83. Itoh, N.; Yonehara, S.; Ishii, A.; Yonehara, M.; Mizushima, S.; Sameshima, M.; Hase, A.; Seto, Y.; Nagata, S. The polypeptide encoded by the cDNA for human cell surface antigen Fas can mediate apoptosis. Cell 1991, 66, 233-243. [CrossRef]

84. Oehm, A.; Behrmann, I.; Falk, W.; Pawlita, M.; Maier, G.; Klas, C.; Li-Weber, M.; Richards, S.; Dhein, J.; Trauth, B.C.; et al. Purification and molecular cloning of the APO-1 cell surface antigen, a member of the tumor necrosis factor/nerve growth factor receptor superfamily. Sequence identity with the Fas antigen. J. Biol. Chem. 1992, 267, 10709-10715. [PubMed]

85. Ogasawara, J.; Watanabe-Fukunaga, R.; Adachi, M.; Matsuzawa, A.; Kasugai, T.; Kitamura, Y.; Itoh, N.; Suda, T.; Nagata, S. Lethal effect of the anti-Fas antibody in mice. Nature 1993, 364, 806-809. [CrossRef] [PubMed]

86. Dickens, L.S.; Boyd, R.S.; Jukes-Jones, R.; Hughes, M.A.; Robinson, G.L.; Fairall, L.; Schwabe, J.W.; Cain, K.; Macfarlane, M. A death effector domain chain DISC model reveals a crucial role for caspase- 8 chain assembly in mediating apoptotic cell death. Mol. Cell 2012, 47, 291-305. [CrossRef] [PubMed]

87. Bodmer, J.L.; Holler, N.; Reynard, S.; Vinciguerra, P.; Schneider, P.; Juo, P.; Blenis, J.; Tschopp, J. TRAIL receptor-2 signals apoptosis through FADD and caspase-8. Nat. Cell Biol. 2000, 2, 241-243. [CrossRef] [PubMed]

88. Schleich, K.; Buchbinder, J.H.; Pietkiewicz, S.; Kahne, T.; Warnken, U.; Ozturk, S.; Schnolzer, M.; Naumann, M.; Krammer, P.H.; Lavrik, I.N. Molecular architecture of the DED chains at the DISC: Regulation of procaspase- 8 activation by short DED proteins c-FLIP and procaspase- 8 prodomain. Cell Death Differ. 2016, 23, 681-694. [CrossRef] [PubMed]

89. Horn, S.; Hughes, M.A.; Schilling, R.; Sticht, C.; Tenev, T.; Ploesser, M.; Meier, P.; Sprick, M.R.; MacFarlane, M.; Leverkus, M. Caspase-10 Negatively Regulates Caspase-8-Mediated Cell Death, Switching the Response to CD95L in Favor of NF-кB Activation and Cell Survival. Cell Rep. 2017, 19, 785-797. [CrossRef] [PubMed]

90. Hinshaw-Makepeace, J.; Huston, G.; Fortner, K.A.; Russell, J.Q.; Holoch, D.; Swain, S.; Budd, R.C. c-FLIP(S) reduces activation of caspase and NF-kB pathways and decreases T cell survival. Eur. J. Immunol. 2008, 38, 54-63. [CrossRef] [PubMed]

91. Dillon, C.P.; Oberst, A.; Weinlich, R.; Janke, L.J.; Kang, T.B.; Ben-Moshe, T.; Mak, T.W.; Wallach, D.; Green, D.R. Survival function of the FADD-CASPASE-8-cFLIP(L) complex. Cell Rep. 2012, 1, 401-407. [CrossRef] [PubMed]

92. Panayotova-Dimitrova, D.; Feoktistova, M.; Ploesser, M.; Kellert, B.; Hupe, M.; Horn, S.; Makarov, R.; Jensen, F.; Porubsky, S.; Schmieder, A.; et al. cFLIP Regulates Skin Homeostasis and Protects against TNF-Induced Keratinocyte Apoptosis. Cell Rep. 2013, 5, 397-408. [CrossRef] [PubMed]

93. Hughes, M.A.; Powley, I.R.; Jukes-Jones, R.; Horn, S.; Feoktistova, M.; Fairall, L.; Schwabe, J.W.R.; Leverkus, M.; Cain, K.; MacFarlane, M. Co-operative and Hierarchical Binding of c-FLIP and Caspase-8: A Unified Model Defines How c-FLIP Isoforms Differentially Control Cell Fate. Mol. Cell 2016, 61, 834-849. [CrossRef] [PubMed]

94. Irmler, M.; Thome, M.; Hahne, M.; Schneider, P.; Hofmann, K.; Steiner, V.; Bodmer, J.L.; Schroter, M.; Burns, K.; Mattmann, C.; et al. Inhibition of death receptor signals by cellular FLIP. Nature 1997, 388, $190-195$. [CrossRef] [PubMed] 
95. Scaffidi, C.; Schmitz, I.; Krammer, P.H.; Peter, M.E. The role of c-FLIP in modulation of CD95-induced apoptosis. J. Biol. Chem. 1999, 274, 1541-1548. [CrossRef] [PubMed]

96. Ozturk, S.; Schleich, K.; Lavrik, I.N. Cellular FLICE-like inhibitory proteins (c-FLIPs): Fine-tuners of life and death decisions. Exp. Cell Res. 2012, 318, 1324-1331. [CrossRef] [PubMed]

97. Krueger, A.; Schmitz, I.; Baumann, S.; Krammer, P.H.; Kirchhoff, S. Cellular FLICE-inhibitory protein splice variants inhibit different steps of caspase-8 activation at the CD95 death-inducing signaling complex. J. Biol. Chem. 2001, 276, 20633-20640. [CrossRef] [PubMed]

98. Vaux, D.L.; Silke, J. IAPs, RINGs and ubiquitylation. Nat. Rev. Mol. Cell Biol. 2005, 6, 287-297. [CrossRef] [PubMed]

99. Holcik, M.; Korneluk, R.G. XIAP, the guardian angel. Nat. Rev. Mol. Cell Biol. 2001, 2, 550-556. [CrossRef] [PubMed]

100. Jost, P.J.; Grabow, S.; Gray, D.; McKenzie, M.D.; Nachbur, U.; Huang, D.C.; Bouillet, P.; Thomas, H.E.; Borner, C.; Silke, J.; et al. XIAP discriminates between type I and type II FAS-induced apoptosis. Nature 2009, 460, 1035-1039. [CrossRef] [PubMed]

101. Bratton, S.B.; Walker, G.; Srinivasula, S.M.; Sun, X.M.; Butterworth, M.; Alnemri, E.S.; Cohen, G.M. Recruitment, activation and retention of caspases- 9 and -3 by Apaf- 1 apoptosome and associated XIAP complexes. EMBO J. 2001, 20, 998-1009. [CrossRef] [PubMed]

102. Deveraux, Q.L.; Roy, N.; Stennicke, H.R.; Van Arsdale, T.; Zhou, Q.; Srinivasula, S.M.; Alnemri, E.S.; Salvesen, G.S.; Reed, J.C. IAPs block apoptotic events induced by caspase- 8 and cytochrome c by direct inhibition of distinct caspases. EMBO J. 1998, 17, 2215-2223. [CrossRef] [PubMed]

103. Hinz, S.; Trauzold, A.; Boenicke, L.; Sandberg, C.; Beckmann, S.; Bayer, E.; Walczak, H.; Kalthoff, H.; Ungefroren, $\mathrm{H}$. Bcl-XL protects pancreatic adenocarcinoma cells against CD95- and TRAIL-receptor-mediated apoptosis. Oncogene 2000, 19, 5477-5486. [CrossRef] [PubMed]

104. Trauzold, A.; Wermann, H.; Arlt, A.; Schutze, S.; Schafer, H.; Oestern, S.; Roder, C.; Ungefroren, H.; Lampe, E.; Heinrich, M.; et al. CD95 and TRAIL receptor-mediated activation of protein kinase C and NF-kB contributes to apoptosis resistance in ductal pancreatic adenocarcinoma cells. Oncogene 2001, 20, 4258-4269. [CrossRef] [PubMed]

105. Shamas-Din, A.; Kale, J.; Leber, B.; Andrews, D.W. Mechanisms of Action of Bcl-2 Family Proteins. Cold Spring Harb. Perspect. Biol. 2013, 5, a008714. [CrossRef] [PubMed]

106. Huang, K.; Zhang, J.; O’Neill, K.L.; Gurumurthy, C.B.; Quadros, R.M.; Tu, Y.; Luo, X. Cleavage by Caspase 8 and Mitochondrial Membrane Association Activate the BH3-only Protein Bid during TRAIL-induced Apoptosis. J. Biol. Chem. 2016, 291, 11843-11851. [CrossRef] [PubMed]

107. Tait, S.W.; Green, D.R. Mitochondria and cell death: Outer membrane permeabilization and beyond. Nat. Rev. Mol. Cell Biol. 2010, 11, 621-632. [CrossRef] [PubMed]

108. Riedl, S.J.; Salvesen, G.S. The apoptosome: Signalling platform of cell death. Nat. Rev. Mol. Cell Biol. 2007, 8, 405-413. [CrossRef] [PubMed]

109. Llambi, F.; Moldoveanu, T.; Tait, S.W.; Bouchier-Hayes, L.; Temirov, J.; McCormick, L.L.; Dillon, C.P.; Green, D.R. A unified model of mammalian BCL-2 protein family interactions at the mitochondria. Mol. Cell 2011, 44, 517-531. [CrossRef] [PubMed]

110. Willis, S.N.; Chen, L.; Dewson, G.; Wei, A.; Naik, E.; Fletcher, J.I.; Adams, J.M.; Huang, D.C. Proapoptotic Bak is sequestered by Mcl-1 and Bcl-xL, but not Bcl-2, until displaced by BH3-only proteins. Genes Dev. 2005, 19, 1294-1305. [CrossRef] [PubMed]

111. Falschlehner, C.; Schaefer, U.; Walczak, H. Following TRAIL's path in the immune system. Immunology 2009, 127, 145-154. [CrossRef] [PubMed]

112. Deng, Y.; Lin, Y.; Wu, X. TRAIL-induced apoptosis requires Bax-dependent mitochondrial release of Smac/DIABLO. Genes Dev. 2002, 16, 33-45. [CrossRef] [PubMed]

113. Ganten, T.M.; Koschny, R.; Sykora, J.; Schulze-Bergkamen, H.; Buchler, P.; Haas, T.L.; Schader, M.B.; Untergasser, A.; Stremmel, W.; Walczak, H. Preclinical differentiation between apparently safe and potentially hepatotoxic applications of TRAIL either alone or in combination with chemotherapeutic drugs. Clin. Cancer Res. 2006, 12, 2640-2646. [CrossRef] [PubMed] 
114. Herbst, R.S.; Eckhardt, S.G.; Kurzrock, R.; Ebbinghaus, S.; O’Dwyer, P.J.; Gordon, M.S.; Novotny, W.; Goldwasser, M.A.; Tohnya, T.M.; Lum, B.L.; et al. Phase I dose-escalation study of recombinant human Apo2L/TRAIL, a dual proapoptotic receptor agonist, in patients with advanced cancer. J. Clin. Oncol. 2010, 28, 2839-2846. [CrossRef] [PubMed]

115. Soria, J.C.; Mark, Z.; Zatloukal, P.; Szima, B.; Albert, I.; Juhasz, E.; Pujol, J.L.; Kozielski, J.; Baker, N.; Smethurst, D.; et al. Randomized phase II study of dulanermin in combination with paclitaxel, carboplatin, and bevacizumab in advanced non-small-cell lung cancer. J. Clin. Oncol. 2011, 29, 4442-4451. [CrossRef] [PubMed]

116. Soria, J.C.; Smit, E.; Khayat, D.; Besse, B.; Yang, X.; Hsu, C.P.; Reese, D.; Wiezorek, J.; Blackhall, F. Phase 1b study of dulanermin (recombinant human Apo2L/TRAIL) in combination with paclitaxel, carboplatin, and bevacizumab in patients with advanced non-squamous non-small-cell lung cancer. J. Clin. Oncol. 2010, 28, 1527-1533. [CrossRef] [PubMed]

117. Yee, L.; Fanale, M.; Dimick, K.; Calvert, S.; Robins, C.; Ing, J.; Ling, J.; Novotny, W.; Ashkenazi, A.; Burris, H., III. A phase IB safety and pharmacokinetic (PK) study of recombinant human Apo2L/TRAIL in combination with rituximab in patients with low-grade non-Hodgkin lymphoma. J. Clin. Oncol. 2007, 25. [CrossRef]

118. Wainberg, Z.A.; Messersmith, W.A.; Peddi, P.F.; Kapp, A.V.; Ashkenazi, A.; Royer-Joo, S.; Portera, C.C.; Kozloff, M.F. A phase 1B study of dulanermin in combination with modified FOLFOX6 plus bevacizumab in patients with metastatic colorectal cancer. Clin. Colorectal Cancer 2013, 12, 248-254. [CrossRef] [PubMed]

119. Yee, L.; Burris, H.A.; Kozloff, M.; Wainberg, Z.; Pao, M.; Skettino, S.; Novotny, W.; Durbin, B.; Weston, J.; Hurwitz, H. Phase Ib study of recombinant human Apo2L/TRAIL plus irinotecan and cetuximab or FOLFIRI in metastatic colorectal cancer (mCRC) patients (pts): Preliminary results. J. Clin. Oncol. 2009, 27. [CrossRef]

120. Kasubhai, S.M.; Bendell, J.C.; Kozloff, M.; Kapp, A.V.; Ashkenazi, A.; Royer-Joo, S.; Portera, C.C. Phase Ib study of dulanermin combined with FOLFIRI (with or without bevacizumab [BV]) in previously treated patients (Pts) with metastatic colorectal cancer (mCRC). J. Clin. Oncol. 2012, 30. [CrossRef]

121. Quintavalle, C.; Condorelli, G. Dulanermin in cancer therapy: Still much to do. Transl. Lung Cancer Res. 2012, 1, 158-159. [PubMed]

122. Kaplan-Lefko, P.J.; Graves, J.D.; Zoog, S.J.; Pan, Y.; Wall, J.; Branstetter, D.G.; Moriguchi, J.; Coxon, A.; Huard, J.N.; $\mathrm{Xu}, \mathrm{R}$.; et al. Conatumumab, a fully human agonist antibody to death receptor 5, induces apoptosis via caspase activation in multiple tumor types. Cancer Biol. Ther. 2010, 9, 618-631. [CrossRef] [PubMed]

123. Rosevear, H.M.; Lightfoot, A.J.; Griffith, T.S. Conatumumab, a fully human mAb against death receptor 5 for the treatment of cancer. Curr. Opin. Investig. Drugs 2010, 11, 688-698. [PubMed]

124. Kindler, H.L.; Garbo, L.; Stephenson, J.; Wiezorek, J.; Sabin, T.; Hsu, M.; Civoli, F.; Richards, D. A phase Ib study to evaluate the safety and efficacy of AMG 655 in combination with gemcitabine $(\mathrm{G})$ in patients (pts) with metastatic pancreatic cancer (PC). J. Clin. Oncol. 2009, 27. [CrossRef]

125. Kindler, H.L.; Richards, D.A.; Stephenson, J.; Garbo, L.E.; Lima, C.S.R.; Safran, H.; Wiezorek, J.S.; Feigal, E.G.; Bray, S.; Fuchs, C. A placebo-controlled, randomized phase II study of conatumumab (C) or AMG 479 (A) or placebo $(\mathrm{P})$ plus gemcitabine $(\mathrm{G})$ in patients (pts) with metastatic pancreatic cancer (mPC). J. Clin. Oncol. 2010, 28. [CrossRef]

126. Kindler, H.L.; Richards, D.A.; Garbo, L.E.; Garon, E.B.; Stephenson, J.J., Jr.; Rocha-Lima, C.M.; Safran, H.; Chan, D.; Kocs, D.M.; Galimi, F.; et al. A randomized, placebo-controlled phase 2 study of ganitumab (AMG 479) or conatumumab (AMG 655) in combination with gemcitabine in patients with metastatic pancreatic cancer. Ann. Oncol. 2012, 23, 2834-2842. [CrossRef] [PubMed]

127. LoRusso, P.; Hong, D.; Heath, E.; Kurzrock, R.; Wang, D.; Hsu, M.; Goyal, L.; Wiezorek, J.; Storgard, C.; Herbst, R. First-in-human study of AMG 655, a pro-apoptotic TRAIL receptor-2 agonist, in adult patients with advanced solid tumors. J. Clin. Oncol. 2007, 25. [CrossRef]

128. Beltran, P.J.; Mitchell, P.; Chung, Y.A.; Cajulis, E.; Lu, J.; Belmontes, B.; Ho, J.; Tsai, M.M.; Zhu, M.; Vonderfecht, S.; et al. AMG 479, a fully human anti-insulin-like growth factor receptor type I monoclonal antibody, inhibits the growth and survival of pancreatic carcinoma cells. Mol. Cancer Ther. 2009, 8, 1095-1105. [CrossRef] [PubMed]

129. Yada, A.; Yazawa, M.; Ishida, S.; Yoshida, H.; Ichikawa, K.; Kurakata, S.; Fujiwara, K. A novel humanized anti-human death receptor 5 antibody CS-1008 induces apoptosis in tumor cells without toxicity in hepatocytes. Ann. Oncol. 2008, 19, 1060-1067. [CrossRef] [PubMed] 
130. Ichikawa, K.; Liu, W.; Zhao, L.; Wang, Z.; Liu, D.; Ohtsuka, T.; Zhang, H.; Mountz, J.D.; Koopman, W.J.; Kimberly, R.P.; et al. Tumoricidal activity of a novel anti-human DR5 monoclonal antibody without hepatocyte cytotoxicity. Nat. Med. 2001, 7, 954-960. [CrossRef] [PubMed]

131. Buchsbaum, D.J.; Zhou, T.; Grizzle, W.E.; Oliver, P.G.; Hammond, C.J.; Zhang, S.; Carpenter, M.; LoBuglio, A.F. Antitumor efficacy of TRA-8 anti-DR5 monoclonal antibody alone or in combination with chemotherapy and/or radiation therapy in a human breast cancer model. Clin. Cancer Res. 2003, 9, 3731-3741. [PubMed]

132. Straughn, J.M., Jr.; Oliver, P.G.; Zhou, T.; Wang, W.; Alvarez, R.D.; Grizzle, W.E.; Buchsbaum, D.J. Anti-tumor activity of TRA-8 anti-death receptor 5 (DR5) monoclonal antibody in combination with chemotherapy and radiation therapy in a cervical cancer model. Gynecol. Oncol. 2006, 101, 46-54. [CrossRef] [PubMed]

133. DeRosier, L.C.; Huang, Z.Q.; Sellers, J.C.; Buchsbaum, D.J.; Vickers, S.M. Treatment with gemcitabine and TRA-8 anti-death receptor- $5 \mathrm{mAb}$ reduces pancreatic adenocarcinoma cell viability in vitro and growth in vivo. J. Gastrointest. Surg. 2006, 10, 1291-1300, discussion 1300. [CrossRef] [PubMed]

134. Derosier, L.C.; Vickers, S.M.; Zinn, K.R.; Huang, Z.; Wang, W.; Grizzle, W.E.; Sellers, J.; Stockard, C.R., Jr.; Zhou, T.; Oliver, P.G.; et al. TRA-8 anti-DR5 monoclonal antibody and gemcitabine induce apoptosis and inhibit radiologically validated orthotopic pancreatic tumor growth. Mol. Cancer Ther. 2007, 6, 3198-3207. [CrossRef] [PubMed]

135. Forero-Torres, A.; Shah, J.; Wood, T.; Posey, J.; Carlisle, R.; Copigneaux, C.; Luo, F.; Wojtowicz-Praga, S.; Percent, I.; Saleh, M. Phase I Trial of Weekly Tigatuzumab, an Agonistic Humanized Monoclonal Antibody Targeting Death Receptor 5 (DR5). Cancer Biother. Radiopharm. 2010, 25, 13-19. [CrossRef] [PubMed]

136. Forero-Torres, A.; Infante, J.R.; Waterhouse, D.; Wong, L.; Vickers, S.; Arrowsmith, E.; He, A.R.; Hart, L.; Trent, D.; Wade, J.; et al. Phase 2, multicenter, open-label study of tigatuzumab (CS-1008), a humanized monoclonal antibody targeting death receptor 5 , in combination with gemcitabine in chemotherapy-naive patients with unresectable or metastatic pancreatic cancer. Cancer Med. 2013, 2, 925-932. [CrossRef] [PubMed]

137. Dhein, J.; Daniel, P.T.; Trauth, B.C.; Oehm, A.; Möller, P.; Krammer, P.H. Induction of apoptosis by monoclonal antibody anti-APO-1 class switch variants is dependent on cross-linking of APO-1 cell surface antigens. J. Immunol. 1992, 149, 3166-3173. [PubMed]

138. Wajant, H.; Moosmayer, D.; Wuest, T.; Bartke, T.; Gerlach, E.; Schonherr, U.; Peters, N.; Scheurich, P.; Pfizenmaier, K. Differential activation of TRAIL-R1 and -2 by soluble and membrane TRAIL allows selective surface antigen-directed activation of TRAIL-R2 by a soluble TRAIL derivative. Oncogene 2001, 20, 4101-4106. [CrossRef] [PubMed]

139. Thurber, G.M.; Schmidt, M.M.; Wittrup, K.D. Antibody tumor penetration: Transport opposed by systemic and antigen-mediated clearance. Adv. Drug Deliv. Rev. 2008, 60, 1421-1434. [CrossRef] [PubMed]

140. Olive, K.P.; Jacobetz, M.A.; Davidson, C.J.; Gopinathan, A.; McIntyre, D.; Honess, D.; Madhu, B.; Goldgraben, M.A.; Caldwell, M.E.; Allard, D.; et al. Inhibition of Hedgehog Signaling Enhances Delivery of Chemotherapy in a Mouse Model of Pancreatic Cancer. Science 2009, 324, 1457-1461. [CrossRef] [PubMed]

141. Koong, A.C.; Mehta, V.K.; Le, Q.T.; Fisher, G.A.; Terris, D.J.; Brown, J.M.; Bastidas, A.J.; Vierra, M. Pancreatic tumors show high levels of hypoxia. Int. J. Radiat. Oncol. Biol. Phys. 2000, 48, 919-922. [CrossRef]

142. Wang, W.; Erbe, A.K.; Hank, J.A.; Morris, Z.S.; Sondel, P.M. NK Cell-Mediated Antibody-Dependent Cellular Cytotoxicity in Cancer Immunotherapy. Front. Immunol. 2015, 6, 368. [CrossRef] [PubMed]

143. Wilson, N.S.; Yang, B.; Yang, A.; Loeser, S.; Marsters, S.; Lawrence, D.; Li, Y.; Pitti, R.; Totpal, K.; Yee, S.; et al. An $\mathrm{F}_{\mathrm{C}} \gamma$ receptor-dependent mechanism drives antibody-mediated target-receptor signaling in cancer cells. Cancer Cell 2011, 19, 101-113. [CrossRef] [PubMed]

144. Graves, J.D.; Kordich, J.J.; Huang, T.H.; Piasecki, J.; Bush, T.L.; Sullivan, T.; Foltz, I.N.; Chang, W.; Douangpanya, H.; Dang, T.; et al. Apo2L/TRAIL and the death receptor 5 agonist antibody AMG 655 cooperate to promote receptor clustering and antitumor activity. Cancer Cell 2014, 26, 177-189. [CrossRef] [PubMed]

145. Tuthill, M.H.; Montinaro, A.; Zinngrebe, J.; Prieske, K.; Draber, P.; Prieske, S.; Newsom-Davis, T.; von Karstedt, S.; Graves, J.; Walczak, H. TRAIL-R2-specific antibodies and recombinant TRAIL can synergise to kill cancer cells. Oncogene 2015, 34, 2138-2144. [CrossRef] [PubMed]

146. Todaro, M.; Lombardo, Y.; Francipane, M.G.; Alea, M.P.; Cammareri, P.; Iovino, F.; Di Stefano, A.B.; Di Bernardo, C.; Agrusa, A.; Condorelli, G.; et al. Apoptosis resistance in epithelial tumors is mediated by tumor-cell-derived interleukin-4. Cell Death Differ. 2008, 15, 762-772. [CrossRef] [PubMed]

147. Newsom-Davis, T.; Prieske, S.; Walczak, H. Is TRAIL the holy grail of cancer therapy? Apoptosis 2009, 14, 607-623. [CrossRef] [PubMed] 
148. Ozawa, F.; Friess, H.; Kleeff, J.; Xu, Z.W.; Zimmermann, A.; Sheikh, M.S.; Büchler, M.W. Effects and expression of TRAIL and its apoptosis-promoting receptors in human pancreatic cancer. Cancer Lett. 2001, 163, 71-81. [CrossRef]

149. Falschlehner, C.; Emmerich, C.H.; Gerlach, B.; Walczak, H. TRAIL signalling: Decisions between life and death. Int. J. Biochem. Cell Biol. 2007, 39, 1462-1475. [CrossRef] [PubMed]

150. Trauzold, A.; Schmiedel, S.; Röder, C.; Tams, C.; Christgen, M.; Oestern, S.; Arlt, A.; Westphal, S.; Kapischke, M.; Ungefroren, H.; et al. Multiple and synergistic deregulations of apoptosis-controlling genes in pancreatic carcinoma cells. Br. J. Cancer 2003, 89, 1714-1721. [CrossRef] [PubMed]

151. Trauzold, A.; Roder, C.; Sipos, B.; Karsten, K.; Arlt, A.; Jiang, P.; Martin-Subero, J.I.; Siegmund, D.; Muerkoster, S.; Pagerols-Raluy, L.; et al. CD95 and TRAF2 promote invasiveness of pancreatic cancer cells. FASEB J. 2005, 19, 620-622. [CrossRef] [PubMed]

152. Wagner, K.W.; Punnoose, E.A.; Januario, T.; Lawrence, D.A.; Pitti, R.M.; Lancaster, K.; Lee, D.; von Goetz, M.; Yee, S.F.; Totpal, K.; et al. Death-receptor O-glycosylation controls tumor-cell sensitivity to the proapoptotic ligand Apo2L/TRAIL. Nat. Med. 2007, 13, 1070. [CrossRef] [PubMed]

153. Dufour, F.; Rattier, T.; Shirley, S.; Picarda, G.; Constantinescu, A.A.; Morle, A.; Zakaria, A.B.; Marcion, G.; Causse, S.; Szegezdi, E.; et al. N-glycosylation of mouse TRAIL-R and human TRAIL-R1 enhances TRAIL-induced death. Cell Death Differ. 2017, 24, 500-510. [CrossRef] [PubMed]

154. Degli-Esposti, M.A.; Dougall, W.C.; Smolak, P.J.; Waugh, J.Y.; Smith, C.A.; Goodwin, R.G. The novel receptor TRAIL-R4 induces NF- $\mathrm{kB}$ and protects against TRAIL-mediated apoptosis, yet retains an incomplete death domain. Immunity 1997, 7, 813-820. [CrossRef]

155. Braeuer, S.J.; Buneker, C.; Mohr, A.; Zwacka, R.M. Constitutively activated nuclear factor- $\kappa$ B, but not induced NF- $k B$, leads to TRAIL resistance by up-regulation of X-linked inhibitor of apoptosis protein in human cancer cells. Mol. Cancer Res. 2006, 4, 715-728. [CrossRef] [PubMed]

156. Wang, C.Y.; Mayo, M.W.; Korneluk, R.G.; Goeddel, D.V.; Baldwin, A.S., Jr. NF-kB antiapoptosis: Induction of TRAF1 and TRAF2 and c-IAP1 and c-IAP2 to suppress caspase-8 activation. Science 1998, 281, 1680-1683. [CrossRef] [PubMed]

157. Micheau, O.; Lens, S.; Gaide, O.; Alevizopoulos, K.; Tschopp, J. NF-кB signals induce the expression of c-FLIP. Mol. Cell. Biol. 2001, 21, 5299-5305. [CrossRef] [PubMed]

158. Roux, J.; Hafner, M.; Bandara, S.; Sims, J.J.; Hudson, H.; Chai, D.; Sorger, P.K. Fractional killing arises from cell-to-cell variability in overcoming a caspase activity threshold. Mol. Syst. Biol. 2015, 11, 803. [CrossRef] [PubMed]

159. Shlyakhtina, Y.; Pavet, V.; Gronemeyer, H. Dual role of DR5 in death and survival signaling leads to TRAIL resistance in cancer cells. Cell Death Dis. 2017, 8, e3025. [CrossRef] [PubMed]

160. Schneider, P.; Thome, M.; Burns, K.; Bodmer, J.L.; Hofmann, K.; Kataoka, T.; Holler, N.; Tschopp, J. TRAIL receptors 1 (DR4) and 2 (DR5) signal FADD-dependent apoptosis and activate NF-KB. Immunity 1997, 7, 831-836. [CrossRef]

161. Tran, S.E.; Holmstrom, T.H.; Ahonen, M.; Kahari, V.M.; Eriksson, J.E. MAPK/ERK overrides the apoptotic signaling from Fas, TNF, and TRAIL receptors. J. Biol. Chem. 2001, 276, 16484-16490. [CrossRef] [PubMed]

162. Morel, J.; Audo, R.; Hahne, M.; Combe, B. Tumor necrosis factor-related apoptosis-inducing ligand (TRAIL) induces rheumatoid arthritis synovial fibroblast proliferation through mitogen-activated protein kinases and phosphatidylinositol 3-kinase/Akt. J. Biol. Chem. 2005, 280, 15709-15718. [CrossRef] [PubMed]

163. Azijli, K.; Weyhenmeyer, B.; Peters, G.J.; de Jong, S.; Kruyt, F.A. Non-canonical kinase signaling by the death ligand TRAIL in cancer cells: Discord in the death receptor family. Cell Death Differ. 2013, 20, 858-868. [CrossRef] [PubMed]

164. Azijli, K.; Yuvaraj, S.; Peppelenbosch, M.P.; Wurdinger, T.; Dekker, H.; Joore, J.; van Dijk, E.; Quax, W.J.; Peters, G.J.; de Jong, S.; et al. Kinome profiling of non-canonical TRAIL signaling reveals RIP1-Src-STAT3-dependent invasion in resistant non-small cell lung cancer cells. J. Cell Sci. 2012, 125 Pt 19, 4651-4661. [CrossRef] [PubMed]

165. Xu, J.; Zhou, J.Y.; Wei, W.Z.; Wu, G.S. Activation of the Akt survival pathway contributes to TRAIL resistance in cancer cells. PLoS ONE 2010, 5, e10226. [CrossRef] [PubMed]

166. Lalaoui, N.; Morlé, A.; Mérino, D.; Jacquemin, G.; Iessi, E.; Morizot, A.; Shirley, S.; Robert, B.; Solary, E.; Garrido, C.; et al. TRAIL-R4 Promotes Tumor Growth and Resistance to Apoptosis in Cervical Carcinoma HeLa Cells through AKT. PLoS ONE 2011, 6, e19679. [CrossRef] [PubMed] 
167. Lafont, E.; Kantari-Mimoun, C.; Draber, P.; De Miguel, D.; Hartwig, T.; Reichert, M.; Kupka, S.; Shimizu, Y.; Taraborrelli, L.; Spit, M.; et al. The linear ubiquitin chain assembly complex regulates TRAIL-induced gene activation and cell death. EMBO J. 2017, 36, 1147-1166. [CrossRef] [PubMed]

168. Ishimura, N.; Isomoto, H.; Bronk, S.F.; Gores, G.J. Trail induces cell migration and invasion in apoptosis-resistant cholangiocarcinoma cells. Am. J. Physiol. Gastrointest. Liver Physiol. 2006, 290, G129-G136. [CrossRef] [PubMed]

169. Trauzold, A.; Siegmund, D.; Schniewind, B.; Sipos, B.; Egberts, J.; Zorenkov, D.; Emme, D.; Roder, C.; Kalthoff, H.; Wajant, H. TRAIL promotes metastasis of human pancreatic ductal adenocarcinoma. Oncogene 2006, 25, 7434-7439. [CrossRef] [PubMed]

170. Von Karstedt, S.; Conti, A.; Nobis, M.; Montinaro, A.; Hartwig, T.; Lemke, J.; Legler, K.; Annewanter, F.; Campbell, A.D.; Taraborrelli, L.; et al. Cancer cell-autonomous TRAIL-R signaling promotes KRAS-driven cancer progression, invasion, and metastasis. Cancer Cell 2015, 27, 561-573. [CrossRef] [PubMed]

171. Hoogwater, F.J.; Nijkamp, M.W.; Smakman, N.; Steller, E.J.; Emmink, B.L.; Westendorp, B.F.; Raats, D.A.; Sprick, M.R.; Schaefer, U.; Van Houdt, W.J.; et al. Oncogenic K-Ras turns death receptors into metastasis-promoting receptors in human and mouse colorectal cancer cells. Gastroenterology 2010, 138, 2357-2367. [CrossRef] [PubMed]

172. Azijli, K.; Yuvaraj, S.; van Roosmalen, I.; Flach, K.; Giovannetti, E.; Peters, G.J.; de Jong, S.; Kruyt, F.A. MAPK p38 and JNK have opposing activities on TRAIL-induced apoptosis activation in NSCLC H460 cells that involves RIP1 and caspase-8 and is mediated by Mcl-1. Apoptosis 2013, 18, 851-860. [CrossRef] [PubMed]

173. Karl, I.; Jossberger-Werner, M.; Schmidt, N.; Horn, S.; Goebeler, M.; Leverkus, M.; Wajant, H.; Giner, T. TRAF2 inhibits TRAIL- and CD95L-induced apoptosis and necroptosis. Cell Death Dis. 2014, 5, e1444. [CrossRef] [PubMed]

174. Varfolomeev, E.; Maecker, H.; Sharp, D.; Lawrence, D.; Renz, M.; Vucic, D.; Ashkenazi, A. Molecular determinants of kinase pathway activation by Apo2 ligand/tumor necrosis factor-related apoptosis-inducing ligand. J. Biol. Chem. 2005, 280, 40599-40608. [CrossRef] [PubMed]

175. Hacker, H.; Karin, M. Regulation and function of IKK and IKK-related kinases. Sci. STKE 2006, 2006, re13. [CrossRef] [PubMed]

176. Bertrand, M.J.; Milutinovic, S.; Dickson, K.M.; Ho, W.C.; Boudreault, A.; Durkin, J.; Gillard, J.W.; Jaquith, J.B.; Morris, S.J.; Barker, P.A. cIAP1 and cIAP2 facilitate cancer cell survival by functioning as E3 ligases that promote RIP1 ubiquitination. Mol. Cell 2008, 30, 689-700. [CrossRef] [PubMed]

177. Rahighi, S.; Ikeda, F.; Kawasaki, M.; Akutsu, M.; Suzuki, N.; Kato, R.; Kensche, T.; Uejima, T.; Bloor, S.; Komander, D.; et al. Specific recognition of linear ubiquitin chains by NEMO is important for NF- $\mathrm{kB}$ activation. Cell 2009, 136, 1098-1109. [PubMed]

178. Ganten, T.M.; Sykora, J.; Koschny, R.; Batke, E.; Aulmann, S.; Mansmann, U.; Stremmel, W.; Sinn, H.P.; Walczak, H. Prognostic significance of tumour necrosis factor-related apoptosis-inducing ligand (TRAIL) receptor expression in patients with breast cancer. J. Mol. Med. 2009, 87, 995-1007. [CrossRef] [PubMed]

179. Macher-Goeppinger, S.; Aulmann, S.; Tagscherer, K.E.; Wagener, N.; Haferkamp, A.; Penzel, R.; Brauckhoff, A.; Hohenfellner, M.; Sykora, J.; Walczak, H.; et al. Prognostic value of tumor necrosis factor-related apoptosis-inducing ligand (TRAIL) and TRAIL receptors in renal cell cancer. Clin. Cancer Res. 2009, 15, 650-659. [CrossRef] [PubMed]

180. Bai, X.; Williams, J.L.; Greenwood, S.L.; Baker, P.N.; Aplin, J.D.; Crocker, I.P. A placental protective role for trophoblast-derived TNF-related apoptosis-inducing ligand (TRAIL). Placenta 2009, 30, 855-860. [CrossRef] [PubMed]

181. Siegmund, D.; Klose, S.; Zhou, D.; Baumann, B.; Roder, C.; Kalthoff, H.; Wajant, H.; Trauzold, A. Role of caspases in CD95L- and TRAIL-induced non-apoptotic signalling in pancreatic tumour cells. Cell. Signal. 2007, 19, 1172-1184. [CrossRef] [PubMed]

182. Bertsch, U.; Röder, C.; Kalthoff, H.; Trauzold, A. Compartmentalization of TNF-related apoptosis-inducing ligand (TRAIL) death receptor functions: Emerging role of nuclear TRAIL-R2. Cell Death Dis. 2014, 5, e1390. [CrossRef] [PubMed]

183. Boyerinas, B.; Park, S.M.; Hau, A.; Murmann, A.E.; Peter, M.E. The role of let-7 in cell differentiation and cancer. Endocr.-Relat. Cancer 2010, 17, F19-F36. [CrossRef] [PubMed]

184. Barh, D.; Malhotra, R.; Ravi, B.; Sindhurani, P. MicroRNA let-7: An emerging next-generation cancer therapeutic. Curr. Oncol. 2010, 17, 70-80. [CrossRef] [PubMed] 
185. Haselmann, V.; Kurz, A.; Bertsch, U.; Hubner, S.; Olempska-Muller, M.; Fritsch, J.; Hasler, R.; Pickl, A.; Fritsche, H.; Annewanter, F.; et al. Nuclear death receptor TRAIL-R2 inhibits maturation of let-7 and promotes proliferation of pancreatic and other tumor cells. Gastroenterology 2014, 146, 278-290. [CrossRef] [PubMed]

186. Fuchs, Y.; Steller, H. Live to die another way: Modes of programmed cell death and the signals emanating from dying cells. Nat. Rev. Mol. Cell Biol. 2015, 16, 329. [CrossRef] [PubMed]

187. Jouan-Lanhouet, S.; Arshad, M.I.; Piquet-Pellorce, C.; Martin-Chouly, C.; Le Moigne-Muller, G.; Van Herreweghe, F.; Takahashi, N.; Sergent, O.; Lagadic-Gossmann, D.; Vandenabeele, P.; et al. TRAIL induces necroptosis involving RIPK1/RIPK3-dependent PARP-1 activation. Cell Death Differ. 2012, 19, 2003. [CrossRef] [PubMed]

188. Meylan, E.; Tschopp, J. The RIP kinases: Crucial integrators of cellular stress. Trends Biochem. Sci. 2005, 30, 151-159. [CrossRef] [PubMed]

189. Cho, Y.S.; Challa, S.; Moquin, D.; Genga, R.; Ray, T.D.; Guildford, M.; Chan, F.K. Phosphorylation-driven assembly of the RIP1-RIP3 complex regulates programmed necrosis and virus-induced inflammation. Cell 2009, 137, 1112-1123. [CrossRef] [PubMed]

190. Oberst, A.; Dillon, C.P.; Weinlich, R.; McCormick, L.L.; Fitzgerald, P.; Pop, C.; Hakem, R.; Salvesen, G.S.; Green, D.R. Catalytic activity of the caspase-8-FLIP(L) complex inhibits RIPK3-dependent necrosis. Nature 2011, 471, 363-367. [CrossRef] [PubMed]

191. Xie, T.; Peng, W.; Liu, Y.; Yan, C.; Maki, J.; Degterev, A.; Yuan, J.; Shi, Y. Structural basis of RIP1 inhibition by necrostatins. Structure 2013, 21, 493-499. [CrossRef] [PubMed]

192. Seifert, L.; Werba, G.; Tiwari, S.; Giao Ly, N.N.; Alothman, S.; Alqunaibit, D.; Avanzi, A.; Barilla, R.; Daley, D.; Greco, S.H.; et al. The necrosome promotes pancreatic oncogenesis via CXCL1 and Mincle-induced immune suppression. Nature 2016, 532, 245-249. [CrossRef] [PubMed]

193. Lemke, J.; von Karstedt, S.; Abd El Hay, M.; Conti, A.; Arce, F.; Montinaro, A.; Papenfuss, K.; El-Bahrawy, M.A.; Walczak, H. Selective CDK9 inhibition overcomes TRAIL resistance by concomitant suppression of cFlip and Mcl-1. Cell Death Differ. 2014, 21, 491-502. [CrossRef] [PubMed]

194. Huang, Y.; Yang, X.; Xu, T.; Kong, Q.; Zhang, Y.; Shen, Y.; Wei, Y.; Wang, G.; Chang, K. Overcoming resistance to TRAIL-induced apoptosis in solid tumor cells by simultaneously targeting death receptors, c-FLIP and IAPs. Int. J. Oncol. 2016, 49, 153-163. [CrossRef] [PubMed]

195. Zhao, K.; Wang, Y.; Wang, X. Tagged and untagged TRAIL show different activity against tumor cells. Oncol. Lett. 2012, 4, 1301-1304. [CrossRef] [PubMed]

196. Holland, P.M. Targeting Apo2L/TRAIL receptors by soluble Apo2L/TRAIL. Cancer Lett. 2013, 332, $156-162$. [CrossRef] [PubMed]

197. Huet, H.A.; Growney, J.D.; Johnson, J.A.; Li, J.; Bilic, S.; Ostrom, L.; Zafari, M.; Kowal, C.; Yang, G.; Royo, A.; et al. Multivalent nanobodies targeting death receptor 5 elicit superior tumor cell killing through efficient caspase induction. $m A$ ss 2014, 6, 1560-1570. [CrossRef] [PubMed]

198. Van Audenhove, I.; Gettemans, J. Nanobodies as Versatile Tools to Understand, Diagnose, Visualize and Treat Cancer. EBioMedicine 2016, 8, 40-48. [CrossRef] [PubMed]

199. Papadopoulos, K.P.; Isaacs, R.; Bilic, S.; Kentsch, K.; Huet, H.A.; Hofmann, M.; Rasco, D.; Kundamal, N.; Tang, Z.; Cooksey, J.; et al. Unexpected hepatotoxicity in a phase I study of TAS266, a novel tetravalent agonistic Nanobody(R) targeting the DR5 receptor. Cancer Chemother. Pharmacol. 2015, 75, 887-895. [CrossRef] [PubMed]

200. Gieffers, C.; Kluge, M.; Merz, C.; Sykora, J.; Thiemann, M.; Schaal, R.; Fischer, C.; Branschadel, M.; Abhari, B.A.; Hohenberger, P.; et al. APG350 induces superior clustering of TRAIL receptors and shows therapeutic antitumor efficacy independent of cross-linking via Fcgamma receptors. Mol. Cancer Ther. 2013, 12, 2735-2747. [CrossRef] [PubMed]

201. Leng, Y.; Hou, J.; Jin, J.; Zhang, M.; Ke, X.; Jiang, B.; Pan, L.; Yang, L.; Zhou, F.; Wang, J.; et al. Circularly permuted TRAIL plus thalidomide and dexamethasone versus thalidomide and dexamethasone for relapsed/refractory multiple myeloma: A phase 2 study. Cancer Chemother. Pharmacol. 2017, 79, 1141-1149. [CrossRef] [PubMed]

202. Geng, C.; Hou, J.; Zhao, Y.; Ke, X.; Wang, Z.; Qiu, L.; Xi, H.; Wang, F.; Wei, N.; Liu, Y.; et al. A multicenter, open-label phase II study of recombinant CPT (Circularly Permuted TRAIL) plus thalidomide in patients with relapsed and refractory multiple myeloma. Am. J. Hematol. 2014, 89, 1037-1042. [CrossRef] [PubMed]

203. Chen, W.; Qiu, L.; Hou, J.; Zhang, X.; Ke, X.; Wang, Z. Phase Ib study of recombinant circularly permuted TRAIL (CPT) in relapsed or refractory multiple myeloma patients. Blood 2012, 120, 1857. 
204. Fang, F.; Wang, A.P.; Yang, S.F. Antitumor activity of a novel recombinant mutant human tumor necrosis factor-related apoptosis-inducing ligand. Acta Pharmacol. Sin. 2005, 26, 1373-1381. [CrossRef] [PubMed]

205. Li, L.; Wen, X.Z.; Bu, Z.D.; Cheng, X.J.; Xing, X.F.; Wang, X.H.; Zhang, L.H.; Guo, T.; Du, H.; Hu, Y.; et al. Paclitaxel enhances tumoricidal potential of TRAIL via inhibition of MAPK in resistant gastric cancer cells. Oncol. Rep. 2016, 35, 3009-3017. [CrossRef] [PubMed]

206. Jaworska, D.; Szliszka, E. Targeting Apoptotic Activity Against Prostate Cancer Stem Cells. Int. J. Mol. Sci. 2017, 18, 1648. [CrossRef] [PubMed]

207. Min, S.Y.; Byeon, H.J.; Lee, C.; Seo, J.; Lee, E.S.; Shin, B.S.; Choi, H.G.; Lee, K.C.; Youn, Y.S. Facile one-pot formulation of TRAIL-embedded paclitaxel-bound albumin nanoparticles for the treatment of pancreatic cancer. Int. J. Pharm. 2015, 494, 506-515. [CrossRef] [PubMed]

208. Wicker, C.A.; Sahu, R.P.; Kulkarni-Datar, K.; Srivastava, S.K.; Brown, T.L. BITC Sensitizes Pancreatic Adenocarcinomas to TRAIL-induced Apoptosis. Cancer Growth Metastasis 2010, 2009, 45-55. [CrossRef] [PubMed]

209. Henrich, C.J.; Brooks, A.D.; Erickson, K.L.; Thomas, C.L.; Bokesch, H.R.; Tewary, P.; Thompson, C.R.; Pompei, R.J.; Gustafson, K.R.; McMahon, J.B.; et al. Withanolide E sensitizes renal carcinoma cells to TRAIL-induced apoptosis by increasing cFLIP degradation. Cell Death Dis. 2015, 6, e1666. [CrossRef] [PubMed]

210. Park, S.H.; Lee, D.H.; Kim, J.L.; Kim, B.R.; Na, Y.J.; Jo, M.J.; Jeong, Y.A.; Lee, S.Y.; Lee, S.I.; Lee, Y.Y.; et al. Metformin enhances TRAIL-induced apoptosis by Mcl-1 degradation via Mule in colorectal cancer cells. Oncotarget 2016, 7, 59503-59518. [CrossRef] [PubMed]

211. Qureshi, M.Z.; Romero, M.A.; Attar, R.; Javed, Z.; Farooqi, A.A. TRAIL and Bortezomib: Killing cancer with two stones. Asian Pac. J. Cancer Prev. 2015, 16, 1671-1674. [CrossRef] [PubMed]

212. Lee, H.S.; Park, S.B.; Kim, S.A.; Kwon, S.K.; Cha, H.; Lee, D.Y.; Ro, S.; Cho, J.M.; Song, S.Y. A novel HDAC inhibitor, CG200745, inhibits pancreatic cancer cell growth and overcomes gemcitabine resistance. Sci. Rep. 2017, 7, 41615. [CrossRef] [PubMed]

213. Kumagai, T.; Wakimoto, N.; Yin, D.; Gery, S.; Kawamata, N.; Takai, N.; Komatsu, N.; Chumakov, A.; Imai, Y.; Koeffler, H.P. Histone deacetylase inhibitor, suberoylanilide hydroxamic acid (Vorinostat, SAHA) profoundly inhibits the growth of human pancreatic cancer cells. Int. J. Cancer 2007, 121, 656-665. [CrossRef] [PubMed]

214. Arhoma, A.; Chantry, A.D.; Haywood-Small, S.L.; Cross, N.A. SAHA-induced TRAIL-sensitisation of Multiple Myeloma cells is enhanced in 3D cell culture. Exp. Cell Res. 2017, 360, 226-235. [CrossRef] [PubMed]

215. Zhou, W.; Feng, X.; Han, H.; Guo, S.; Wang, G. Synergistic effects of combined treatment with histone deacetylase inhibitor suberoylanilide hydroxamic acid and TRAIL on human breast cancer cells. Sci. Rep. 2016, 6, 28004. [CrossRef] [PubMed]

216. Hari, Y.; Harashima, N.; Tajima, Y.; Harada, M. Bcl-xL inhibition by molecular-targeting drugs sensitizes human pancreatic cancer cells to TRAIL. Oncotarget 2015, 6, 41902-41915. [CrossRef] [PubMed]

217. Perimenis, P.; Galaris, A.; Voulgari, A.; Prassa, M.; Pintzas, A. IAP antagonists Birinapant and AT-406 efficiently synergise with either TRAIL, BRAF, or BCL-2 inhibitors to sensitise BRAFV600E colorectal tumour cells to apoptosis. BMC Cancer 2016, 16, 624. [CrossRef] [PubMed]

218. Wu, M.S.; Wang, G.F.; Zhao, Z.Q.; Liang, Y.; Wang, H.B.; Wu, M.Y.; Min, P.; Chen, L.Z.; Feng, Q.S.; Bei, J.X.; et al. Smac mimetics in combination with TRAIL selectively target cancer stem cells in nasopharyngeal carcinoma. Mol. Cancer Ther. 2013, 12, 1728-1737. [CrossRef] [PubMed]

219. Stern, H.M.; Padilla, M.; Wagner, K.; Amler, L.; Ashkenazi, A. Development of immunohistochemistry assays to assess GALNT14 and FUT3/6 in clinical trials of dulanermin and drozitumab. Clin. Cancer Res. 2010, 16, 1587-1596. [CrossRef] [PubMed]

(C) 2018 by the authors. Licensee MDPI, Basel, Switzerland. This article is an open access article distributed under the terms and conditions of the Creative Commons Attribution (CC BY) license (http://creativecommons.org/licenses/by/4.0/). 